\title{
Hazard Identification and Characterization: Criteria for Categorizing Shiga Toxin- Producing Escherichia coli on a Risk Basis
}

\section{FAO WHO Stec Expert Grp}

Published in:

Journal of Food Protection

Link to article, DOI:

10.4315/0362-028X.JFP-18-291

Publication date:

2019

Document Version

Publisher's PDF, also known as Version of record

Link back to DTU Orbit

Citation (APA):

FAO WHO Stec Expert Grp (2019). Hazard Identification and Characterization: Criteria for Categorizing Shiga Toxin-Producing Escherichia coli on a Risk Basis. Journal of Food Protection, 82(1), 7-21. https://doi.org/10.4315/0362-028X.JFP-18-291

\section{General rights}

Copyright and moral rights for the publications made accessible in the public portal are retained by the authors and/or other copyright owners and it is a condition of accessing publications that users recognise and abide by the legal requirements associated with these rights.

- Users may download and print one copy of any publication from the public portal for the purpose of private study or research.

- You may not further distribute the material or use it for any profit-making activity or commercial gain

- You may freely distribute the URL identifying the publication in the public portal 


\title{
General Interest
}

\section{Hazard Identification and Characterization: Criteria for Categorizing Shiga Toxin-Producing Escherichia coli on a Risk Basis ${ }^{\dagger}$}

\author{
FAO/WHO STEC EXPERT GROUP
}

The Joint FAO/WHO Expert Meetings on Microbiological Risk Assessment (JEMRA) Secretariat, * Food Safety and Quality Unit, Agriculture and Consumer Protection Department, Food and Agriculture Organization of the United Nations, Viale delle Terme di Caracalla, 00153 Rome, Italy

MS 18-291: Received 24 June 2018/Accepted 16 August 2018/Published Online 26 December 2018

\begin{abstract}
Shiga toxin-producing Escherichia coli (STEC) comprise a large, highly diverse group of strains. Since the emergence of STEC serotype O157:H7 as an important foodborne pathogen, serotype data have been used for identifying STEC strains, and this use continued as other serotypes were implicated in human infections. An estimated 470 STEC serotypes have been identified, which can produce one or more of the 12 known Shiga toxin (Stx) subtypes. The number of STEC serotypes that cause human illness varies but is probably higher than 100. However, many STEC virulence genes are mobile and can be lost or transferred to other bacteria; therefore, STEC strains that have the same serotype may not carry the same virulence genes or pose the same risk. Although serotype information is useful in outbreak investigations and surveillance studies, it is not a reliable means of assessing the human health risk posed by a particular STEC serotype. To contribute to the development of a set of criteria that would more reliably support hazard identification, this review considered each of the factors contributing to a negative human health outcome: mild diarrhea, bloody diarrhea, and hemolytic uremic syndrome (HUS). STEC pathogenesis involves entry into the human gut (often via ingestion), attachment to the intestinal epithelial cells, and elaboration of Stx. Production of Stx, which disrupts normal cellular functions and causes cell damage, alone without adherence of bacterial cells to gut epithelial cells is insufficient to cause severe illness. The principal adherence factor in STEC is the intimin protein coded by the eae gene. The aggregative adherence fimbriae adhesins regulated by the aggR gene of enteroaggregative $E$. coli strains are also effective adherence factors. The $s t x_{2 \mathrm{a}}$ gene is most often present in locus of enterocyte effacement (eae)-positive STEC

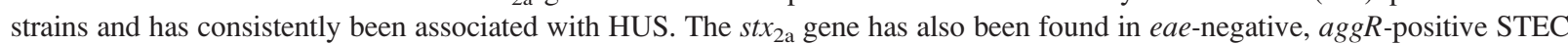
that have caused HUS. HUS cases where other stx gene subtypes were identified indicate that other factors such as host susceptibility and the genetic cocktail of virulence genes in individual isolates may affect their association with severe diseases.
\end{abstract}

Key words: Characterization; Risk criteria; Shiga toxin-producing Escherichia coli

Shiga toxin-producing Escherichia coli (STEC) is a large, complex group of $E$. coli strains that vary greatly in phenotypic, serologic, and genotypic characteristics. STEC pathogenesis is highly complex, requiring multiple virulence factors to cause severe diseases. Some of these virulence factors have many subtypes or alleles, not all of which seem to affect humans. Many of these STEC proven and putative virulence factors reside on mobile genetic elements and can be lost or transferred. As a result, strains of the same serotype may have different virulence genes and pose different health risks. The Food and Agriculture Organization of the United Nations (FAO) and the World Health

\footnotetext{
* Author for correspondence. Tel: + 3906 57053614; Fax: + 3906 57053057; E-mail: Jeffrey.Lejeune@fao.org.

$\dagger$ Appeared as Annex 5 in the FAO/WHO Meeting Report on Shiga toxin-producing Escherichia coli (STEC) and food: attribution, characterization, and monitoring. Microbiological risk assessment series 31. Available at: http://www.fao.org/3/ca0032en/CA0032EN. pdf. Slightly modified to fit the format of the Journal of Food Protection.
}

Organization (WHO) were asked to provide advice to the Codex Committee on Food Hygiene on a number of aspects related management of STEC in the food chain, one of which was the identification of the hazard. A Joint FAO/ WHO Expert Meeting on Microbiological Risk Assessment (JEMRA) Group was convened to address this issue. The JEMRA Group decided that a set of criteria and/or a decision tree (http://www.fao.org/3/ca0032en/CA0032EN. pdf) based on current knowledge of factors known to be required in STEC pathogenesis and of phenotypes historically linked with disease should be developed to provide a harmonized risk-based approach for characterization of STEC isolated from a food or along the food chain. A database of strains and serotypes could be developed to facilitate application of the decision tree. For example, the database could include information on strains that have certain patterns when assessed against the criteria used in the decision tree and historically linked in different regions with various levels of health risk from severe to minimal or when no known risk has been reported. This characterization, 
together with other factors such as knowledge of the intrinsic nature of the food, further handling that may affect survival, food preparation practices before consumption, and whether the food is to be provided to known high-risk consumer groups, could be used for determining the potential human health risk posed by an STEC strain found in the food chain.

Pathogenicity of STEC is complex, but in general infection entails three features: ingestion of a contaminated food or other vehicle, colonization of intestinal epithelial cells by STEC, and production of Shiga toxins (Stx), which disrupt normal cellular functions and cause cell damage. The evidence suggests that production of Stx alone without adherence of bacterial cells to gut epithelial cells is insufficient to cause severe illness. STEC infection can be asymptomatic. Most people who come to medical attention have diarrhea, which is often bloody and can be hemorrhagic (hence the term enterohemorrhagic E. coli). Hemolytic uremic syndrome (HUS) is the most important complication (58), and some patients with HUS develop chronic renal failure. People with STEC infection with or without HUS can die. This risk-based discussion focuses on mild diarrhea, bloody diarrhea (BD), and HUS.

\section{ADHERENCE FACTORS}

The majority of STEC known to cause BD or HUS have virulence factors that enable attachment to intestinal epithelial cells, so adherence factors are generally considered essential for severe illness and perhaps even for nonBD. The main adherence factor in STEC is the intimin protein coded by the eae gene that resides on the locus of enterocyte effacement (LEE) pathogenicity island. Intimin is also a virulence factor of enteropathogenic E. coli (EPEC) and is crucial in the attaching-effacing lesion that has been associated with EPEC and LEE-positive STEC strains (78). The eae gene is highly polymorphic, with over 34 genetic variants (alleles) $(72,89)$, which are designated by Greek letters. For example, E. coli O157:H7 carries $\gamma$ (gamma) eae, serotype O26:H11 often has $\beta$ (beta) eae, and serotype O121:H19 has $\varepsilon$ (epsilon) eae. The presence of both eae and the Stx gene $s t x_{2}$ is a reliable predictor that the STEC strain may cause BD or HUS (40).

LEE-negative (i.e., eae-negative) STEC has been implicated as a cause of severe disease (112). For example, an STEC O113:H21 strain was first isolated from a child with HUS in 1983 (83), and this serotype later caused a cluster of HUS cases in Australia (122). STEC O91:H21 strains that are also LEE negative have been implicated in HUS cases in Germany (99, 100). LEE-negative STEC strains probably have other means or mechanisms for adherence (36). The O113:H21 strains have the STEC agglutinating adhesin (121). The $s a b$ gene that codes for an outer membrane autotransporter protein that enhances biofilm formation (70) is also thought to be an adherence factor. Evaluations of other STEC strains have revealed the presence of paa, efal, ompA, lpfA, and other genes that code for adhesins (78). The plasmid-borne to $B$ gene also codes for an adhesin and is found in O157:H7 and many LEEpositive STEC strains, including strains of the O26, O121, and $\mathrm{O} 145$ serogroups, and in EPEC strains (154). The toxBencoded adhesin is thought to contribute to the adherence properties of the 0157:H7 serotype. However, like other adhesins, the role of the toxB adhesin in STEC virulence has not been fully determined, so this adhesin is often regarded as a putative virulence factor, and its prevalence differs among STEC strains (42). In a recent study, an 86-kb mosaic pathogenicity island (PAI) named the locus of adhesion and autoaggregation (LAA) was reported, which is composed of four modules of 80 genes, including those that code for novel and known virulence factors associated with adherence and autoaggregation (104). Phylogenomic analysis revealed that LAA appears to be exclusively present in a subset of emerging LEE-negative STEC strains, including strains from hemorrhagic colitis and HUS cases. LAA acquisition may be a recent evolutionary event, which may have contributed to the emergence of these STEC strains (104).

By far the most compelling evidence that adherence is critical to severe disease outcome is the enteroaggregative $E$. coli (EAEC) O104:H4 strain, which caused the large HUS outbreak in Germany in 2011 (48). EAEC strains do not have eae but have the aggregative adherence fimbriae (AAF) adhesins regulated by the $a g g R$ gene. The ability of O104:H4 strains to aggregate on epithelial cells coupled with Stx 2 production resulted in a remarkably high HUS rate of $22 \%$ (20). This outbreak indicated that an adherence factor other than eae, in combination with stx $x_{2 a}$, can produce severe disease (8). Some public health agencies are now testing STEC for both eae and $a g g R$ to detect EAEC strains that have acquired the ability to produce Stx. Because the $\operatorname{aggR}$ genes reside on plasmids that can be lost after disease is produced, chromosomal markers such as the aaiC gene have also been used to identify EAEC strains (38).

\section{Key Points on Adherence Factors}

1. Adherence factors are critical factors for STEC pathogenicity.

2. The principal adherence factor in STEC is the intimin protein coded by the eae gene.

3. The AAF adhesins regulated by the $a g g R$ gene of EAEC are also effective adherence factors.

4. Other putative STEC adherence factors include those coded by genes saa, sab, paa, efal, ompA, lpfA, toxB, and the LAA PAI.

\section{STX TYPES AND SUBTYPES}

STEC are characterized by the production of Stx, of which two main types have been described, Stx1 and Stx2, with three Stx1 (Stx1a, Stx1c, and Stx1d) and seven Stx2 (Stx2a, Stx2b, Stx2c, Stx2d, Stx2e, Stx2f, and Stx2g) subtypes (137). A novel subtype of Stx1, Stx1e (GenBank accession no. KF926684), which has limited reactivity with anti-Stx1 antibodies, has been found in Enterobacter cloacae (128). Provisional designations also have been proposed (88) for two new Stx2 subtypes, encoded by genes stx $_{2 \mathrm{~h}}$ (GenBank AM904726) and st $x_{2 \mathrm{i}}$ (GenBank FN252457), but the proposed sequence of $s t x_{2 \mathrm{~h}}$ was found to be identical to the already published variant $s t x_{2 \mathrm{e}}-\mathrm{O} 8-\mathrm{FHI}-$ 1106-1092 (137). STEC strains can produce any of the Stx or a combination of Stx subtypes, but not all subtypes have 
been implicated in severe illness $(71,96)$. For example, among the Stx1 group, little is known about the clinical significance of the Stx1d subtype. Stx1c is the most common subtype in strains isolated from sheep, wild deer, and wildlife meats $(24,71,106)$; these strains often do not produce intimin and tend to cause asymptomatic infection or mild diarrhea (51). The Stx1a subtype is often produced by LEE-positive STEC strains that have caused severe infections, including serotypes O157:H7, O26:H11, and O111:H8. Brooks et al. (25) found that $83 \%$ of O26, $50 \%$ of O111, and $100 \%$ of 0103 strains that caused BD in the United States carried $s t x_{1}$ and eae, but of these, only one O111 strain was implicated in HUS. Consistent with those observations, O103:H2 is the second most common STEC causing infection in Norway but is not associated with HUS (110). These three $\mathrm{O}$ groups have been declared as adulterants in raw nonintact beef and intact beef products intended for nonintact use in the United States (156). Some STEC serotypes with st $x_{1 \mathrm{a}}$ and eae are found in foods (45) but have not been implicated in human infections, suggesting that not all STEC that produce Stx1a and have eae pose the same health risk. STEC with $s t x_{1 \mathrm{c}}$, either alone or together with $s t x_{2 \mathrm{~b}}$, is often isolated from wild ruminants. Most of these strains are eae negative (71), so their presence in humans has not received much attention. However, in some studies 10 to $15 \%$ of clinical samples from patients with diarrheal illnesses have been positive for $s t x_{1 \mathrm{c}}$ and/or $\operatorname{stx}_{2 \mathrm{~b}}(22,26,32,47)$.

Stx2 is more important than Stx 1 in the development of HUS (35). Among the Stx 2 group, the subtypes most often associated with severe disease are Stx2a, Stx2c, and Stx2d $(50,124)$. Some researchers have suggested that other subtypes may also cause severe infections. Some Stx2 subtypes share high gene sequence similarities and have probably been misidentified in some reports. The nomenclature for Stx subtypes is continually being refined. Increased use of whole genome sequencing should help to clarify the associations of Stx subtypes with severe diseases. Whole genome sequencing results have also indicated that different stx subtypes are associated with different virulence profiles. In a study from The Netherlands, the genes $e h x A$ and ureC were significantly associated with HUS-associated STEC strains but not with the presence of eae (49), suggesting that these genes could be important pathogenicity markers next to eae and $s t x_{2 \mathrm{a}}$.

The Stx $2 b$ subtype was proposed to designate a strain subtype with a variant of the $s t x_{2 \mathrm{c}}$ gene but that did not cause HUS (124). Analysis of STEC in Europe revealed that $s t x_{2 \mathrm{~b}}$ alone or together with stx $x_{1 \mathrm{c}}$ is common in STEC from deer droppings and wildlife populations $(71,106)$ but does not appear to cause severe human illness $(21,27,32,47)$. The Stx2e subtype is mostly found in isolates from pigs and pork meat (9) and is commonly associated with pig edema disease (7). STEC with $s t x_{2 \mathrm{e}}$ have been isolated from fresh produce (45) and rarely from humans; in one study the frequency of isolation of STEC with $s t x_{2 \mathrm{e}}$ was similar among people with and without diarrhea (50). In another study, isolation of Stx2e-producing STEC was not correlated with diarrheal illness (7), suggesting that Stx2e-producing strains are generally not pathogenic for humans. However, Fasel et al. (41) reported the isolation of an STEC O51:H49 strain with $s t x_{2 \mathrm{e}}$ and eae from a 65 -year-old patient with HUS in Switzerland, and in another study, $s t x_{2 \mathrm{e}}$ was found in STEC $\mathrm{O} 9 \mathrm{abH} \mathrm{H}^{-}$and $\mathrm{O} 101: \mathrm{H}^{-}$strains isolated from an HUS patient (151).

The Stx2f subtype has a genetic sequence that is very distinct from that of the other Stx2 subtypes, and the designation Stx2f was first applied to STEC strains isolated from pigeons (139), although this subtype was first reported as Shiga-like toxin IIva from an STEC strain isolated from an infant with diarrhea (56). Analyses of STEC isolates from the wild, from bovine farm environments, and from humans have seldom found Stx2f $(50,71,103)$. Some studies suggested that an STEC strain that produce Stx $2 \mathrm{f}$ can cause mild diarrhea or can be asymptomatic $(54,126)$, but it appears to be rare $(71,124)$. However, in a recent study an STEC O8:H19 strain that carried both $s x_{2 \mathrm{f}}$ and eae was isolated from an HUS patient in The Netherlands (53), and others have also reported isolating Stx2f-producing STEC strains from HUS patients (63). Additional information is needed to understand the association between Stx2 $\mathrm{f}$ and severe illness.

STEC with the Stx2g subtype was first isolated from bacteriophages in water with fecal contamination (57). The Stx2g subtype was also found in $8.4 \%$ of the STEC strains isolated from farm environments (103) and in some STEC strains isolated from foods (9). STEC strains with $s t x_{2 \mathrm{~g}}$ have rarely been isolated from human samples (9). Such a strain was isolated from German patients with diarrhea, fever, and abdominal pain but has not been implicated in severe diseases (125).

Several researchers have indicated that subtypes Stx2a or Stx2d are significantly associated with the risk of BD, HUS, or both $(22,26,40,94,99,124)$. These subtypes were at least 25 times more potent than Stx2b and Stx2c in cytotoxicity assays using primary human renal proximal tubule epithelial cells and Vero cells (55). In mice, the potencies of Stx2b and Stx2c are similar to those of Stx1, whereas Stx2a and Stx2d were 40 to 400 times more potent than Stx1 (55).

In STEC O157:H7, four major and two minor subtypes of $s t x_{2}$-encoding bacteriophages have been studied to determine the production of Stx2a (115). One of the two bacteriophage subclades in clade 8 , a hypervirulent lineage of serotype O157:H7, confers the highest Stx2a production in the host strain (115). Striking phage-related variability in toxin production has been observed in clinical isolates of $\mathrm{O} 157$ as well as in other O groups (O83, O111, and O145). The genotype of the bacteriophage and host strain factors are relevant to STEC pathogenesis (158) as was recently demonstrated in a whole genome sequencing comparison of Stx2f-producing STEC strains, some of which were isolated from patients with HUS (63). In that study, only the three strains isolated from HUS patients had the EPECassociated efal gene, which resides on the PAI OI122, the STEC plasmid genes $e h x A$, espP , and katP and intimin type $\xi$ (xi) or $\beta$. The $s t x_{2 \mathrm{f}}$ STEC strains isolated from patients with diarrhea but without HUS and the strains isolated from pigeons lacked these genes (63). Although some of these genes, such as ehxA that codes for enterohemolysin, are 
prevalent in STEC strains that have caused severe infections, their role in STEC pathogenesis remains undetermined. Nevertheless, this example suggests that the genotype of the host strain can have an effect on disease outcomes.

The Stx $2 \mathrm{~d}$ subtype has been suggested as an indicator for severe clinical outcomes such as BD or HUS (12). This subtype used to be known as $s t x_{2 \mathrm{~d}}$ activatable because it was activated by elastase in mucus to become 10- to 1,000-fold more cytotoxic (102). In a French outbreak caused by a hybrid STEC-extraintestinal pathogenic E. coli (ExPEC) strain of serotype O80:H2, stx $2 \mathrm{~d}$ in combination with other stx subtypes was found in $69 \%$ of the 52 strains isolated from HUS patients. Among the isolates, $62 \%$ had $s t x_{2 \mathrm{c} / 2 \mathrm{~d}}$, $7 \%$ had $s t x_{2 \mathrm{a} / 2 \mathrm{~d}}$, and $31 \%$ had unique variants of $s t x_{2 \mathrm{a}}(22 \%)$ or $\operatorname{stx}_{2 \mathrm{~d}}(9 \%)$. All 52 strains had the intimin variant eae- $\xi$, and $87 \%$ carried the ehxA gene (95). All 52 O80:H2 strains examined also shared the four genes (sitA, cia, $h l y F$, and ompT) that are characteristic of the ExPEC pS88 plasmid and other ExPEC traits, 98\% carried the iss and iroN genes, $96 \%$ had the cvaA gene, and $61 \%$ had the iucC and etsC genes (142). In a study in Spain, 236 STEC strains isolated from patients with HUS, diarrhea, or both were evaluated. Of these, 193 were eae positive, 43 were eae negative, and 7 (3\%) carried $s t x_{2 \mathrm{~d}}(135)$. Further analysis revealed that six of the st $x_{2 \mathrm{~d}}$-bearing strains were eae-negative STEC of serotypes O73:H18, O91:H21, O148:H8, O181:H49, and ONT:H21 and one was an O157:H7 strain that was also positive for $s t x_{2 \mathrm{c}}$ and eae. In a study of 32 isolates of O26:H11 sequence type 29 recovered from patients with HUS between 2010 and 2013 in France, 7 isolates were positive for $s t x_{2 \mathrm{~d}}$, eae- $\beta$, and SP_26_E (using a CRISPRbased assay) but lacked any of the usual plasmid genes associated with $\mathrm{O} 26$ strains (33). Although these findings indicate that Stx2d causes severe infections, not all STEC strains with $s t x_{2 \mathrm{~d}}$ may causes severe disease. For example, nine patients in Norway infected with an st $x_{2 \mathrm{~d}}$-positive STEC strain did not develop HUS (22). In an outbreak of gastroenteritis in Japan, both Escherichia albertii and STEC O183:H18 that were st $_{2 \mathrm{~d}}$ positive were isolated, but none of the 44 patients examined developed BD or HUS $(21,118)$. In a large study of 626 STEC infections in Germany, none of the 268 HUS patients were infected with an STEC strain that was positive for $s t x_{2 \mathrm{~d}}(50)$. At least 18 genetic variants of the st $_{2 \mathrm{~d}}$ subtype have been identified, and eight of the strains tested were variable in being activatable by elastase (137), which may account for the variability in clinical outcomes associated with Stx2d strains.

Because of sequence similarities, genes $s t x_{2 \mathrm{a}}, s t x_{2 \mathrm{c}}$, and st $x_{2 \mathrm{~d}}$ can be quite difficult to discern and identify (137). The st $x_{2 \mathrm{c}}$-positive strains had been thought to cause severe disease and HUS $(37,50,124)$, but recent information has doubts about this assumption. For example, the European Food Safety Authority (EFSA) Panel on Biological Hazards (37) stated that O111 strains isolated from HUS patients (162) were $s t x_{2 \mathrm{c}}$ positive. However, the alignment of the two sequenced strains revealed $100 \%$ homology with the stx 2 sequences found in O157:H7 strain EDL933, which is known to have $s t x_{2 \mathrm{a}}$ but not stx $x_{2 \mathrm{c}}$ (137). Persson et al. (124) examined 20 STEC strains isolated from HUS patients and found only 1 strain that had $s t x_{2 c}$ alone. That strain has since been sequenced (unpublished data) and identified as belonging to clade 8 of $0157: \mathrm{H} 7$, which is known to have $s x_{2 \mathrm{a}}$ but not $s t x_{2 \mathrm{c}}(115)$. Friedrich et al. (50) did not find a significant difference in the prevalence of $s t x_{2 c}$ between STEC isolates from patients with HUS versus those from patients with diarrhea $(P=0.49)$ nor between isolates from patients with HUS versus those from asymptomatic patients $(P=0.74)$. Additional data obtained with discriminating molecular subtyping methods may clarify whether $s t x_{2 \mathrm{c}}$ is strongly associated with severe disease.

Large genotypic differences in stx phage have also been observed in LEE-negative STEC strains (146). The virulence potential of STEC is quite likely determined by a combination of factors, including bacteriophage clade, stx subtype, and genotype of the bacterial host. Consistent with those assumptions, identification of the specific stx subtype, the bacteriophage mechanisms that control Stx production, and selected virulence genes carried by a particular STEC strain would be useful for assessing health risks, especially considering that not all Stx subtypes appear to affect humans and that some subtypes are more often associated with severe illnesses than are others.

\section{Key Points on Stx}

1. Twelve subtypes of Stx have thus far been identified: Stx1a, Stx1c, Stx1d, Stx1e, and Stx2 subtypes Stx2a to Stx $2 \mathrm{~g}$, and Stx $2 \mathrm{i}$, encoded by genes $s t x_{1 \mathrm{a}}$, stx $x_{1 \mathrm{c}}$, st $x_{1 \mathrm{~d}}$, $s t x_{1 \mathrm{e}}, s t x_{2 \mathrm{a}}$ to $s t x_{2 \mathrm{~g}}$, and $s t x_{2 \mathrm{i}}$, respectively.

2. The gene $s t x_{2 \mathrm{a}}$ is often found in LEE (eae)-positive STEC and has consistently been associated with HUS.

3. The gene $s t x_{2 \mathrm{a}}$ has also been found in eae-negative, aggR-positive STEC that have caused HUS.

4. The gene $s t x_{2 \mathrm{~d}}$ in LEE-negative strains has to a lesser degree been reported from cases of HUS, but not all STEC strains with $s t x_{2 \mathrm{~d}}$ may cause severe disease.

5. HUS cases associated with other Stx subtypes have been identified, indicating that other factors such as host susceptibility, the genetic cocktail of virulence genes in individual isolates, and other (bacteriophage related) factors may affect the association of other Stx subtypes with severe disease.

\section{SEROTYPES AND REGIONAL DIVERSITY}

E. coli strains are typically identified serologically by two surface antigens; the somatic $(\mathrm{O})$ and the flagellar $(\mathrm{H})$, of which there are $\sim 186$ and 53 types, respectively. The serotype identity of STEC strains has been used widely to identify STEC strains with the potential to cause severe diseases, but serotype is not a virulence factor and $E$. coli strains can carry any combination of $\mathrm{O}$ and $\mathrm{H}$ antigens; thus, the number of $E$. coli serotypes is very large. An estimated 470 STEC serotypes have been reported (105) that can produce any one of the 12 Stx 1 and Stx2 subtypes or combinations of these subtypes. However, not all Stx subtypes appear to cause human illness, possibly because these strains lack known adherence factors associated with human illness. The estimated number of STEC serotypes that causes human illness ranges from $>60$ (4) to $>100$ (77). 
Incidences of STEC strains causing foodborne infections have been reported from numerous countries worldwide (77). Serotype O157:H7 is the prototypic STEC that has caused infections worldwide. Serotype O26:H11 also seems prevalent and has caused infections in many countries, but other serotypes have caused infections only in a particular country or region $(5,98,120)$, suggesting that there may be regional variations in STEC serotypes of importance. For example, in 2009, the EFSA (37) identified STEC with stx and eae from five O groups (O157, O26, O103, O111, and O145), also known as the "big 5," as being of health concern in the European Union (EU). Similarly, in the United States, six O types (O26, O45, O103, O111, O121, and O145), or the "big 6," have been found to account for $>75 \%$ of clinical non-O157 STEC infections $(25,68)$. As a result, in 2011, the U.S. Department of Agriculture Food Safety Inspection Service (156) declared the "big 6" STEC O types that carry stx and eae and the STEC 0157 strains as adulterants in raw nonintact beef and intact beef products intended for nonintact use. Although many of these $\mathrm{O}$ types of importance identified by various public health agencies are the same, types 0121 and O45, which are on the U.S. priority list, are not listed as types of concern in other countries (77).

The evidence for geographic clustering and divergence seems to apply to both different STEC serotypes and strains within serotypes. Mellor et al. (101) used multilocus genotyping to examine $\mathrm{O} 157: \mathrm{H} 7$ strains isolated in the United States versus Australia and found that the strains differed in both genotype and genetic markers and virulence genes. Feng et al. (43) used multilocus sequence typing to characterize O113:H21 strains that have caused HUS in Australia versus environmental and clinical strains isolated elsewhere in the world and found that even though all the strains were within the same STEC clonal group, the Australian O113:H21 strains were of sequence type 820, which was not observed in the other strains.

STEC serotypes are evolving and moving among countries, partly because of the ease of worldwide travel, the vast international commerce of foods, and migration of wildlife (106). For example, an atypical O157:H7 variant that ferments sorbitol (SFO157) was first identified in Bavaria, Germany, in 1988 (80) and has now been found in other EU countries, including Finland (39), Austria, Czech Republic (17), and Scotland (2). SFO157 strains seem to be better able to adhere than do other O157 STEC $(52,132)$. Perhaps related to this difference are reports that a higher percentage of individuals with SFO157 infections develop HUS than do individuals with other O157 STEC infections (2, 132). Analysis of SFO157 strains isolated from various EU countries revealed identical or near identical pulsed-field gel electrophoresis (PFGE) profiles, suggesting that the same strains may have spread between the countries (44). SFO157 strains have thus far not been isolated in the United States but have been found in Australia (6), Egypt (134), and Korea (90); however, some of the strains described in those reports had genetic traits different from those of the German SFO157 strain, including the presence of $s t x_{1}$. Most STEC O26:H11 strains were initially found to produce only Stx1, but isolates obtained later produced both Stx1 and Stx2.
Since the mid-1990s, a new clone of O26:H11 that produces only Stx 2 has emerged in Europe and has caused several outbreaks of severe disease $(1,18,31,79,92,119,141,157$, 163, 164). STEC O26 strains have also been isolated from cases of HUS in Argentina (131), and O26 was the most common non-O157 STEC serotype isolated from 1983 to 2002 (25) and 2000 to 2010 (62) in the United States. Among the $\mathrm{O} 26$ human isolates in the United States from 1983 to 2002 , $13 \%$ had $s t x_{2}$, of which only $2 \%$ had $s t x_{2}$ alone and the other $11 \%$ also had stx $_{1}(25)$. Another example of changing regional clustering is STEC O121, which was not listed as being of concern in many countries (77), but together with O26, O103, O111, O117, and O145, O121 was listed as the third most common among the top six nonO157 STEC serogroups associated with serious illness in Canada (29). A strain of serotype O121:H19 (stx 2 positive) was implicated in a 2017 Canadian outbreak suspected to have been associated with contaminated flour (108). STEC O104 became a concern in the United States (77) because of an outbreak of BD in 1994 associated with milk contaminated with a strain of O104:H21 (30). However, the large outbreak of O104:H4 infection in Germany and France in 2011 (48) quickly raised our awareness of the health risks of this serotype and sent a cautionary message concerning the difficulties of anticipating STEC serotypes that may emerge to cause severe illness. The O104:H4 outbreak strain has not been found in the United States except for one strain isolated from a patient who had travelled to Germany during the outbreak period, thus highlighting the risk of pathogen spread via travel.

Identification of the serotype of STEC causing a particular group of infections is important in epidemiology for detection, investigating outbreak incidences, and tracking global emergence. However, E. coli serotyping is complex because of the large number of $\mathrm{O}$ and $\mathrm{H}$ antigens that exist, and not all E. coli isolates can be serotyped. Studies of STEC and enterotoxigenic E. coli (ETEC) strains isolated from fresh produce revealed that $>50 \%$ of the isolates could not be typed or yielded only partial serotypes $(45,46)$. Because many STEC virulence genes are on mobile genetic elements that can be lost or transferred, it is not unusual to find STEC strains of the same serotype that carry different virulence genes and pose different health risks. As a result, although serotype data can be useful for identifying STEC strains, these data should not be assessed independently but rather evaluated along with the other attributes when determining health risks.

\section{Key Points on Serotypes and Diversity}

1. At least 470 STEC serotypes can produce any one or more of the 12 known Stx subtypes.

2. The number of STEC serotypes that cause human illness differs depending on reports but is probably $>100$.

3. Serotype is not a virulence factor and does not (necessarily) predict the virulence profile and health risks associated with a particular STEC but is useful in outbreak investigations and for prevalence surveillance. 


\section{OTHER FACTORS THAT AFFECT VIRULENCE CHARACTERIZATION}

Horizontal gene transfer. Mobile genetic elements such as plasmids, bacteriophages, transposons, PAIs, and insertion sequence elements play a major role in the evolution of E. coli (161). Plasmids are highly diverse and may possess genes for antibiotic resistance, virulence, regulation, and adhesins. Through the process of conjugation, plasmids can transfer small or large fragments of DNA between bacteria and convey various traits to the recipient. Some bacteriophages have the capacity to mobilize genes, as indicated by the enormous proportion of fecal phage particles that contain bacterial DNA. Through lysogenic conversion of resident intestinal bacteria, phage may introduce new phenotypic traits, such as antibiotic resistance and the ability to produce exotoxins (23). Stx-converting bacteriophage (Stx phage) carry the stx gene and can lysogenize nonpathogenic bacterial strains and convert them into STEC (69). Stx phage, therefore, represent highly mobile genetic elements that play an important role in Stx expression, in horizontal gene transfer, and in STEC genome diversification. One example is the Stx-producing EAEC O104:H4 strain, which caused a large outbreak in Germany in 2011 (48). Some researchers have hypothesized that this strain originated from a genetically primitive lineage of $E$. coli in a confined geographical area but evolved via several independent streams of horizontal gene exchange $(11,14$, 130).

Evidence from Central Europe and Italy indicates that O26:H11 strains have been shifting from carrying st $x_{1}$ only to carrying stx $x_{1}$ and $s t x_{2}$ and now to carrying stx $x_{2}$ only and that those strains with only $s t x_{2}$ are more virulent than the other $\mathrm{O} 26$ strains $(1,13,18)$. As a further complication, loss and gain of Stx-encoding phage has been observed in O26:H11 strains (15). In the United States, mostly st $x_{1}$ bearing $\mathrm{O} 26$ strains have been found in foods, and isolation of strains with $s t x_{2}$ alone has thus far not been common.

Frequent loss of stx genes in clinical STEC isolates has been observed upon subcultivation (81), and stx-negative $E$. coli $\mathrm{O} 157: \mathrm{H} 7 / \mathrm{H}^{-}$variants may occur at a low frequency in patients with diarrhea or HUS $(34,138)$. The loss and gain of Stx-encoding phage from $E$. coli in the human intestine or during cultivation can result in strains with different pathotypes. Such strains can present challenges for DNA fingerprinting techniques (such as PFGE), resulting in variable diagnostic results, and can have clinical, epidemiological, and evolutionary implications.

Free and infectious stx phage can be found in high densities in fecal samples from healthy humans, in environments polluted with human and animal feces, and in foods $(73,97,109)$. As a result, molecular detection of stx genes in a sample merely reflects the presence of st $x$ genes (phage), and results will have to be confirmed through isolation and characterization of the STEC strain. Other enterobacterial species also known to acquire stx phage are Shigella dysenteriae type 1, Shigella flexneri, Shigella sonnei, Citrobacter freundii, E. albertii, Acinetobacter haemolyticus, Aeromonas caviae, and E. cloacae (3, 10,
21, 28, 64, 69, 84, 117), and these genes may also be detected by stx-specific assays. Usually, detection of one or more stx genes in foods associated with an outbreak coupled with supporting epidemiological data provide sufficient information to link the food to human illness. However, free stx phage found in foods may result in false-positive findings. Alternative methods that can eliminate or significantly reduce the detection of free stx phage may allow more specific detection of STEC in foods (129).

More than 170 PAIs carrying important virulence properties have been annotated as genomic islands in the sequences of the STEC O157:H7 strains EDL933 and Sakai $(67,123)$. One of these PAIs carries the LEE, which has the eae gene necessary for the attaching and effacing lesion. Another PAI, designated O island 122 (OI-122), carries the large virulence gene cluster efal-lifA $(85,113,145)$ and has frequently been found in STEC strains associated with severe human disease $(82,87,107)$. OI-122 has multiple other functions and appears to be involved in cell adhesion, immunosuppression, disruption of epithelial barrier function, and intestinal colonization (86).

Another important PAI is OI-57, which harbors adfO, a putative virulence gene for adhesion, and $c k f$, which encodes a putative killing factor for bacterial cells. OI-57 is present in the majority of the STEC genomes and in a proportion of human EPEC, suggesting that this PAI could be involved in the attaching and effacing colonization of the intestinal mucosa (74).

A more complete description of many of the additional mobile genetic elements is beyond the scope of this assessment, but a few examples of recombinant strains derived from these elements, also referred to as hybrid strains, deserve mention here.

EAEC-STEC. E. coli O104:H4 from the German outbreak in 2011 has $s_{2} x_{2 a}$ and EAEC pAA (the virulence plasmid with genes coding for AAF/I, AggR, and SepA), extended-spectrum $\beta$-lactamase antibiotic resistance plasmid, and chromosomal genes for Aat (dispersin translocator), SigA (IgA protease-like homolog), and Pic (serine protease precursor) $(19,20)$.

EPEC-STEC. E. coli serotypes O26:H11, O55:H9, and O80:H2 from HUS patients in Austria and Italy have stx ${ }_{2 \mathrm{f}}$, the EPEC-associated efal gene that resides on PAI OI-122, the STEC plasmid genes $e h x A$, espP, and katP, and intimin types $\xi$ or $\beta$ (63).

ExPEC-STEC. E. coli O80:H2 strains reported from France and Spain have $s t x_{2 \mathrm{a}}$, st $x_{2 \mathrm{c}}$, or $s t x_{2 \mathrm{~d}}$, intimin gene eae$\xi$, and at least four genes characteristic of pS88 (sitA, cia, $h l y F$, and ompT) and other genes associated with ExPEC virulence (iss, iroN, and $c v a A$ ) (142). Thirteen O2:H6 strains with sequence type 141 had $s t x_{2 b}, s a a$, and ExPECassociated genes vat, $c l b$ island, $c d i A B^{-}$, and $y b t$ clusters; 12 also had iro, 10 had $\alpha$-hly, cnfl, the pap cluster, and hek, and 9 also had the sfaII cluster (16). 
ETEC-STEC. An E. coli $\mathrm{O} 2: \mathrm{H} 27$ strain with stx $2 \mathrm{a}$, $e h x A$, and estla (gene for ETEC heat-stable toxin) was isolated from two people (one had diarrhea and one was asymptomatic), and an O101:NM strain with stx $2 \mathrm{a}$, ehxA, estIa, and eae was isolated from a patient with HUS in Finland (114). E. coli O159:HUT sequence type 171, with st $x_{2 \mathrm{a}}$, elt (gene for ETEC heat-labile toxin), and ETEC colonization factor $C S 12$, was isolated from a patient with diarrhea in Korea (116). Four O15:H16, five O175:H28, two O136:HNM, and one ONT:H16 human clinical isolate from Germany were positive for st $x_{2 \mathrm{~g}}$ and estIa (the O15:H16 strains were also positive for the plasmid-encoded $a s t A$ and espP) (125).

A less well-characterized st $_{2 \mathrm{f}}$-positive O8:H19 isolate from a patient with HUS in The Netherlands was also positive for the eae gene but negative for ehxA (54). STEC O8:H19 strains do not usually have stx $_{2 \mathrm{f}}$.

In summary, mobile DNA and horizontal gene transfer in $E$. coli can transfer virulence genes to other bacteria and pose an ongoing challenge in diagnostic procedures and detection methodology and in making health risk determinations for STEC found in foods.

\section{Key Points on Horizontal Gene Transfer}

1. Independent streams of horizontal gene exchange play a major role in STEC diversity.

2. Mobile DNA and horizontal gene transfer in E. coli poses an ongoing challenge for diagnostic and detection methods and for the risk assessment of STEC found in foods.

3. Other diarrheagenic E. coli pathotypes are also known to acquire stx phage.

4. Other species of Enterobacteriaceae are also known to acquire stx phage.

Dose-response assessment for STEC virulence types. Stx is the main STEC virulence factor, but it is seldom produced in foods unless the food has undergone severe time and temperature abuse. Significant production of Stx 1 can occur in milk and ground beef when these have been subjected to vigorous aeration at $37^{\circ} \mathrm{C}$ for $48 \mathrm{~h}$ (159). However, these conditions are seldom encountered in normal food production processes because they result in spoilage, which will render the food unfit for consumption. Foodborne STEC infections typically occur from ingesting STEC-contaminated food and other vehicles. The STEC cells then bind to intestinal epithelial cells and express Stx. The severity of disease outcomes in STEC infections may also depend on the number of STEC cells ingested. The infectious doses of STEC are suspected to be low but can differ depending on serotype and strain. Disease outcomes also can differ depending on the individual's susceptibility.

Limited information is available on the dose-response of STEC. The risk of life threatening illness in humans and the absence of an animal model that replicates human pathology preclude experimental determination of the STEC dose-response. Estimates of dose-response have been made for STEC O157:H7 based levels of the pathogen in food and consumption data from patients in outbreaks. Exposure to $<100$ cells of STEC 0157:H7 may be sufficient to cause infection. Exposure estimates have been reported from three outbreaks in which the level of STEC 0157:H7 in the food at consumption could be determined: 2 to 45 cells in salami (152), <700 cells in beef patties (155), and 31 to 35 cells in pumpkin salad with seafood sauce (150). These estimates are supported by reports of STEC O157:H7 levels (expressed either as CFU or most probable number [MPN]) in a variety of foods involved in outbreaks: raw milk cheeses, 5 to $10 \mathrm{CFU} / \mathrm{g}$ (147) and 0.0037 to 0.0095 MPN/g (60), and beef patties, $1.45 \mathrm{MPN} / \mathrm{g}$ (65) and 0.022 $\mathrm{MPN} / \mathrm{g}$ (59). The probability of infection after exposure to a single viable STEC O157 cell is significant. In one foodborne outbreak, the median probability was estimated as $25 \%$ for children and $17 \%$ for adults (150). The frequency of transmission in childcare centers and among family members also suggests that the probability of infection per cell is significant.

It is not known whether the dose-response of STEC strains that use intimin for attachment differs among serogroups, although because of the known genetic and physiological variability of STEC the differences can be presumed to be significant. However, it is not currently possible to identify STEC strains that have a higher probability of causing infection than does STEC O157:H7. An investigation of an STEC infection outbreak involving serotypes $\mathrm{O} 145: \mathrm{H} 28$ and $\mathrm{O} 26: \mathrm{H} 11$ in ice cream revealed levels of $2.4 \mathrm{MPN} / \mathrm{g}$ for $\mathrm{O} 145$ and $0.03 \mathrm{MPN} / \mathrm{g}$ for $\mathrm{O} 26$ (27). In an outbreak of STEC O111: $\mathrm{H}^{-}$infection associated with fermented sausage, the estimated exposure dose was 1 cell per $10 \mathrm{~g}$ (120). Thus, the probability of infection upon exposure to other STEC strains may approach that of O157:H7.

In addition to STEC strain factors, host factors very likely also affect dose-response relationships and disease outcomes. Individuals with weakened immune systems, such as frail or elderly persons, and individuals that lack acquired immunity, such as young children, have the highest rate of illness and HUS (66). In one study in Germany, examination of the relation between major STEC O groups and the affected individual's age and severity of illness revealed that age was a relevant factor in the severity of STEC illness (127). In another study in Germany, in children younger than 3 years of age, the relevant risk factors were contact with ruminants and consumption of raw milk; foods such as meats and sausages were not STEC risk factors until the children were at least 10 years old (160). These factors should be considered when extrapolating doseresponse estimates to different demographic groups or epidemiological scenarios. Heterogeneity in exposure as influenced by infectivity, dose, attack rates, host susceptibility, food, etc. also needs to be taken into account when determining dose-responses in O157:H7 outbreaks (149).

\section{Key Points on Dose-Response}

1. The severity of disease outcome from infections may depend on the number of STEC cells ingested. 
2. The infectious dose of STEC is suspected to be low but can differ among serotypes and among strains.

3. Disease outcome severity differs depending on an individual's susceptibility.

Human and other factors. Although selected STEC traits may be used to assess potential health risks, they provide no conclusive prediction on the outcome or the severity of disease. STEC pathogenesis is highly complex, and aside from STEC virulence traits other factors may also play a role in disease outcome. For example, coculturing O157:H7 strains with commensal E. coli can increase Stx2 production and the virulence of $0157: \mathrm{H} 7$ strains in mice, suggesting that there is a synergistic effect of STEC and the typical intestinal bacteria (61). Some clades of O157:H7 overexpress Stx 2 and are more often associated with severe human infections (111). Severity of STEC infection outcomes can also be affected by synergistic effects with other organisms. In a 2001 to 2010 survey of 1,800 nonO157 STEC infections, $3.6 \%$ of the cases had multiple etiologies (93). In some cases, patients were coinfected with a non-O157 STEC and O157:H7, Cryptosporidium, or Campylobacter. Coinfections with pathogenic E. coli and other pathogens have been characterized by severe diarrhea (153).

The occurrence and severity of STEC infections are also affected by human factors and genetics, which can affect STEC colonization and thus the severity of STEC infection outcomes (133). The impact of human individual susceptibility is also indicated by reports of asymptomatic STEC carriers (144). In a study of fecal samples from 5,590 asymptomatic workers from the Swiss meat processing industry, $3.5 \%$ of the samples were positive for stx genes, 47 STEC strains were isolated, and some strains also had the eae gene, including one isolate of the 0157:H7 serotype (143). In a study in northern Italy of fecal samples from 350 asymptomatic farm workers from 276 dairy farms and 50 abattoir workers from seven facilities, $1.1 \%$ of the farm workers were infected with O157:H7 strains that had eae plus $s t x_{1}$, st $x_{2}$, or both (140). All of these individuals were adults, and although they were asymptomatic, they could have posed health risks to younger individuals. An asymptomatic mother with an eae-negative O146:H28 strain with $s t x_{2 \mathrm{~b}}$, a Stx subtype usually associated with asymptomatic carriage (143), transmitted the strain to her child, resulting in a neonatal case of HUS (148).

Other evidence on the effects of human factors include a case in Finland, where an eae-negative, st $x_{1 \mathrm{c}}$-positive $\mathrm{O} 78: \mathrm{H}^{-}$strain was isolated from the fecal samples of all five family members (91). The Stx1c subtype is most prevalent in STEC strains from sheep (24), and infections by Stx1c-producing strains tends to be mild or asymptomatic (51). Accordingly, the parents and the older siblings had no symptoms, but the 2-year-old child developed HUS. In another study, 3-year-old identical twins were infected with the same O157:H7 strain but had different outcomes; one twin developed HUS but the other did not (75). The authors speculated that differences in inoculum size may have impacted the disease outcomes. These examples suggest that human genetics and individual susceptibility can greatly contribute to disease outcomes. Hence, no STEC strain may be "without risk"; all STEC strains probably pose some health risk to some individuals but maybe not to everyone. Thus, instead of the commonly used terms such as pathogenic and nonpathogenic, perhaps STEC strains should more appropriately be designated as having a low or high health risk. Such terminologies have been proposed and advocated by others for distinguishing the health risk associated with STEC strains $(88,136)$.

Medical histories can reveal that a particular STEC serotype has caused severe infections and outbreaks; therefore, serotype information may be useful when characterizing the STEC health risks, but such data need to be interpreted with caution. STEC strains of serotype O8:H19 have been found in flour in the United States and are common in cattle (76), and an O8:H19 strain also was reported to have caused HUS in a boy in The Netherlands (54). Most O8:H19 strains do not have eae and can have st $x_{1 \mathrm{a}}$, st $x_{2 \mathrm{a}}$, or both genes, but the HUS-causing strain from The Netherlands was unusual in that it had eae and $s t x_{2 \mathrm{f}}$. Most of the STEC virulence genes reside on mobile genetic elements that can be transferred between strains and, as evident from various studies, strains with the same serotype can have different virulence genes and therefore can differ in their potential to cause severe illnesses. The case in The Netherlands also shows that under certain circumstances st $x_{2 \mathrm{f}}$ can cause severe disease, supporting the conclusion that all STEC strains can pose health risks to certain individuals. The fact that strains of the same serotype can differ in pathotype greatly complicates health risk decision making and indicates the difficulty in establishing uniform criteria that can be used to determine whether an STEC has the potential to cause severe disease. Future research may identify better traits that can be used in STEC health risk characterization, in which case the critical health risk criteria currently used will need to be modified accordingly.

\section{Key Points on Human and Other Factors}

1. Human factors are thought to play a role in the outcome and severity of STEC diseases, but this role is undetermined.

2. All STEC strains have the potential to cause diarrhea and pose some health risks, but those that carry certain virulence traits are regarded as high risk and can cause HUS.

\section{CONCLUSIONS}

1. Adherence factors are critical for STEC pathogenicity.

2. The principal adherence factor in STEC is the intimin protein coded by the eae gene.

3. The AAF adhesins regulated by the $a g g R$ gene of EAEC are also an effective means for adherence.

4. Other putative adherence factor genes are $s a a, s a b, p a a$, efal, ompA, lpfA, toxB, and the LAA PAI.

5. Twelve subtypes of Stx have been identified: Stx1a, Stx1c, Stx1d, Stx1e, Stx2a to Stx2g, and Stx2i, encoded 
by genes $s t x_{1 \mathrm{a}}$, st $x_{1 \mathrm{c}}, s t x_{1 \mathrm{~d}}, s t x_{1 e}$, stx $x_{2 a}$ to $s t x_{2 g}$, and $s t x_{2 i}$, respectively.

6. The gene $s t x_{2 \mathrm{a}}$ is most often present in LEE (eae)positive STEC and has consistently been associated with HUS.

7. The gene $s t x_{2 \mathrm{a}}$ has also been found in eae-negative, aggR-positive STEC that have caused HUS.

8. The gene $s t x_{2 \mathrm{~d}}$ in LEE-negative STEC has, to a lesser degree, been reported from HUS cases, but not all STEC strains with $s t x_{2 \mathrm{~d}}$ cause severe disease.

9. HUS cases in which other Stx subtypes were identified indicate that other factors such as host susceptibility and the genetic cocktail of virulence genes in an individual isolate may affect the association of these other Stx subtypes with severe diseases.

10. An estimated 470 STEC serotypes can produce any one or more of the 12 known Stx subtypes.

11. The number of STEC serotypes that cause human illness differs depending on the individual report and is probably $>100$.

12. Serotype is not a virulence factor and does not (necessarily) predict risk or virulence profile of an STEC strain but is useful in outbreak investigations and for prevalence and surveillance studies.

13. Independent horizontal gene exchanges play a major role in STEC pathogenicity and diversity.

14. Mobile DNA and horizontal gene transfer in E. coli transfers virulence genes to other bacteria and poses an ongoing challenge to diagnostic procedures and detection methodologies and to the risk assessment of STEC findings.

15. Other diarrheagenic E. coli pathotypes are known to acquire stx phage.

16. Other species of Enterobacteriaceae are also known to acquire stx phage.

17. The severity of disease outcome in infections may depend on the number of STEC cells ingested.

18. The infectious dose of STEC is suspected to be low but can differ between serotypes and strains.

19. Disease outcomes differ depending on individual susceptibility.

20. Human factors are thought to play a role in STEC diseases, but this role is undetermined.

\section{ACKNOWLEDGMENTS}

The JEMRA Secretariat expresses appreciation to Dr. Peter Feng and Dr. Flemming Scheutz for leading the preparation of this background article on STEC hazard characterization, to Dr. Patricia Griffin and Dr. Alex Gill for critical review of the document, and to Dr. Patricia Desmarchelier for critical editing. The views expressed in this publication are those of the authors and do not necessarily reflect the views or policies of the Food and Agriculture Organization of the United Nations.

\section{REFERENCES}

1. Allerberger, F., A. W. Friedrich, K. Grif, M. P. Dierich, H. J. Dornbusch, C. J. Mache, E. Nachbaur, M. Freilinger, P. Rieck, M. Wagner, A. Caprioli, H. Karch, and L. B. Zimmerhackl. 2003. Hemolytic-uremic syndrome associated with enterohemorrhagic Escherichia coli $\mathrm{O} 26: \mathrm{H}$ infection and consumption of unpasteurized cow's milk. Int. J. Infect. Dis. 7:42-45. doi:10.1016/S12019712(03)90041-5.
2. Allison, L. 2002. HUS due to a sorbitol-fermenting verotoxigenic $E$. coli $\mathrm{O} 157$ in Scotland. Euro. Surveill. Wkly. 6:021031. Available at: http://www.eurosurveillance.org/ew/2002./021031.asp\#2.

3. Alperi, A., and M. J. Figueras. 2010. Human isolates of Aeromonas possess Shiga toxin genes $\left(s t x_{1}\right.$ and $\left.s t x_{2}\right)$ highly similar to the most virulent gene variants of Escherichia coli. Clin. Microbiol. Infect. 16:1563-1567. doi:10.1111/j.1469-0691.2010.03203.x.

4. Bettelheim, K. A. 2003. Non-O157 verotoxin-producing Escherichia coli: a problem, paradox, and paradigm. Exp. Biol. Med. 228:333344. doi:10.1177/153537020322800402.

5. Bettelheim, K. A., and P. N. Goldwater. 2013. Shigatoxigenic Escherichia coli in Australia: a review. Rev. Med. Microbiol. 24:2230. doi:10.1097/MRM.0b013e328358ac88.

6. Bettelheim, K. A., M. Whipp, S. P. Djordjevic, and V. Ramachandran. 2002. First isolation outside Europe of sorbitol-fermenting verocytotoxigenic Escherichia coli (VTEC) belonging to O group O157. J. Med. Microbiol. 51:713-714.

7. Beutin, L., U. Krüger, G. Krause, A. Miko, A. Martin, and E. Strauch. 2008. Evaluation of major types of Shiga toxin 2eproducing Escherichia coli bacteria present in food, pigs, and the environment as potential pathogens for humans. Appl. Environ. Microbiol. 74:4806-4816. doi:10.1128/AEM.00623-08.

8. Beutin, L., and A. Martin. 2012. Outbreak of Shiga toxin-producing Escherichia coli (STEC) O104:H4 infection in Germany causes a paradigm shift with regard to human pathogenicity of STEC strains. J. Food Prot. 75:408-418. doi:10.4315/0362-028X.JFP-11-452.

9. Beutin, L., A. Miko, G. Krause, K. Pries, S. Haby, K. Steege, and N. Albrecht. 2007. Identification of human-pathogenic strains of Shiga toxin-producing Escherichia coli from food by a combination of serotyping and molecular typing of Shiga toxin genes. Appl. Environ. Microbiol. 73:4769-4775. doi:10.1128/AEM.00873-07.

10. Beutin, L., E. Strauch, and I. Fischer. 1999. Isolation of Shigella sonnei lysogenic for a bacteriophage encoding gene for production of Shiga toxin. Lancet 353:1498. doi:10.1016/S01406736(99)00961-7.

11. Bezuidt, O., R. Pierneef, K. Mncube, G. Lima-Mendez, and O. N. Reva. 2011. Mainstreams of horizontal gene exchange in enterobacteria: consideration of the outbreak of enterohemorrhagic E. coli O104:H4 in Germany in 2011. PLoS One 6:e25702. doi:10.1371/ journal.pone.0025702.

12. Bielaszewska, M., A. W. Friedrich, T. Aldick, R. Schürk-Bulgrin, and H. Karch. 2006. Shiga toxin activatable by intestinal mucus in Escherichia coli isolated from humans: predictor for a severe clinical outcome. Clin. Infect. Dis. 43:1160-1167. doi:10.1086/508195.

13. Bielaszewska, M., A. Mellmann, S. Bletz, W. Zhang, R. Köck, A. Kossow, R. Prager, A. Fruth, D. Orth-Höller, M. Marejková, S. Morabito, A. Caprioli, D. Piérard, G. Smith, C. Jenkins, K. Čurová, and H. Karch. 2013. Enterohemorrhagic Escherichia coli O26:H11/ $\mathrm{H}^{-}$: a new virulent clone emerges in Europe. Clin. Infect. Dis. 56:1373-1381. doi:10.1093/cid/cit055.

14. Bielaszewska, M., A. Mellmann, W. Zhang, R. Köck, A. Fruth, A. Bauwens, G. Peters, and H. Karch. 2011. Characterisation of the Escherichia coli strain associated with an outbreak of haemolytic uraemic syndrome in Germany, 2011: a microbiological study. Lancet Infect. Dis. 11:671-676. doi:10.1016/S1473-3099(11)701657.

15. Bielaszewska, M., R. Prager, R. Köck, A. Mellmann, W. Zhang, H. Tschäpe, P. I. Tarr, and H. Karch. 2007. Shiga toxin gene loss and transfer in vitro and in vivo during enterohemorrhagic Escherichia coli $\mathrm{O} 26$ infection in humans. Appl. Environ. Microbiol. 73:31443150. doi:10.1128/AEM.02937-06.

16. Bielaszewska, M., R. Schiller, L. Lammers, A. Bauwens, A. Fruth, B. Middendorf, M. A. Schmidt, P. I. Tarr, U. Dobrindt, H. Karch, and A. Mellmann. 2014. Heteropathogenic virulence and phylogeny reveal phased pathogenic metamorphosis in Escherichia coli O2:H6. EMBO Mol. Med. 6:347-357. doi:10.1002/emmm.201303133.

17. Bielaszewska, M., H. Schmidt, M. A. Karmali, R. Khakhria, J. Janda, K. Bláhová, and H. Karch. 1998. Isolation and characterization of sorbitol-fermenting Shiga toxin (verocytotoxin)-producing 
Escherichia coli $\mathrm{O} 157: \mathrm{H}^{-}$strains in the Czech Republic. J. Clin. Microbiol. 36:2135-2137.

18. Bielaszewska, M., W. Zhang, A. Mellmann, and H. Karch. 2007. Enterohaemorrhagic Escherichia coli $\mathrm{O} 26: \mathrm{H}_{11} / \mathrm{H}^{-}$: a human pathogen in emergence. Berl. Munch. Tierarztl. Wochenschr. 120:279-287.

19. Boisen, N., A. M. Hansen, A. R. Melton-Celsa, T. Zangari, N. P. Mortensen, J. B. Kaper, A. D. O'Brien, and J. P. Nataro. 2014. The presence of the pAA plasmid in the German O104:H4 Shiga toxin type 2a (Stx2a)-producing enteroaggregative Escherichia coli strain promotes the translocation of Stx2a across an epithelial cell monolayer. J. Infect. Dis. 210:1909-1919. doi:10.1093/infdis/ jiu399.

20. Boisen, N., A. R. Melton-Celsa, F. Scheutz, A. D. O'Brien, and J. P. Nataro. 2015. Shiga toxin 2a and enteroaggregative Escherichia coli-a deadly combination. Gut Microbes 6:272-278. doi:10.1080/ 19490976.2015.1054591.

21. Brandal, L. T., H. S. Tunsjø, T. E. Ranheim, I. Løbersli, H. Lange, and A. L. Wester. 2015. Shiga toxin 2a in Escherichia albertii. $J$ Clin. Microbiol. 53:1454-1455. doi:10.1128/JCM.03378-14.

22. Brandal, L. T., A. L. Wester, H. Lange, I. Løbersli, B. A. Lindstedt, L. Vold, and G. Kapperud. 2015. Shiga toxin-producing Escherichia coli infections in Norway, 1992-2012: characterization of isolates and identification of risk factors for haemolytic uremic syndrome. BMC Infect. Dis. 15:324. doi:10.1186/s12879-015-10176.

23. Breitbart, M., I. Hewson, B. Felts, J. M. Mahaffy, J. Nulton, P. Salamon, and F. Rohwer. 2003. Metagenomic analyses of an uncultured viral community from human feces. J. Bacteriol. 185:6220-6223. doi:10.1128/JB.185.20.6220-6223.2003.

24. Brett, K. N., V. Ramachandran, M. A. Hornitzky, K. A. Bettelheim, M. J. Walker, and S. P. Djordjevic. 2003. Stx1c is the most common Shiga toxin 1 subtype among Shiga toxin-producing Escherichia coli isolates from sheep but not among isolates from cattle. J. Clin. Microbiol. 41:926-936. doi:10.1128/JCM.41.3.926-936.2003.

25. Brooks, J. T., E. G. Sowers, J. G. Wells, K. D. Greene, P. M. Griffin, R. M. Hoekstra, and N. A. Strockbine. 2005. Non-O157 Shiga toxin-producing Escherichia coli infections in the United States, 1983-2002. J. Infect. Dis. 192:1422-1429. doi:10.1086/466536.

26. Buvens, G., Y. D. Gheldre, A. Dediste, A. I. de Moreau, G. Mascart, A. Simon, D. Allemeersch, F. Scheutz, S. Lauwers, and D. Piérard. 2012. Incidence and virulence determinants of verocytotoxinproducing Escherichia coli infections in the Brussels-Capital Region, Belgium, in 2008-2010. J. Clin. Microbiol. 50:13361345. doi:10.1128/JCM.05317-11.

27. Buvens, G., B. Possé, K. De Schrijver, L. De Zutter, S. Lauwers, and D. Piérard. 2011. Virulence profiling and quantification of verocytotoxin-producing Escherichia coli O145:H28 and O26:H11 isolated during an ice cream-related hemolytic uremic syndrome outbreak. Foodborne Pathog. Dis. 8:421-426. doi:10.1089/fpd. 2010.0693 .

28. Carter, C. C., J. Fierer, W. W. Chiu, D. J. Looney, M. Strain, and S. R. Mehta. 2016. A novel Shiga toxin 1a-converting bacteriophage of Shigella sonnei with close relationship to Shiga toxin 2converting pages [sic] of Escherichia coli. Open Forum Infect. Dis. 3:ofw079. doi:10.1093/ofid/ofw079.

29. Catford, A., V. Kouamé, A. Martinez-Perez, A. Gill, E. Buenaventura, H. Couture, and J. M. Farber. 2014. Risk profile on nonO157 verotoxin-producing Escherichia coli in produce, beef, milk and dairy products in Canada. Int. Food Risk Anal. J. 4:1-25.

30. Centers for Disease Control and Prevention. 1995. Outbreak of acute gastroenteritis attributable to Escherichia coli serotype O104:H21Helena, Montana, 1994. JAMA (J. Am. Med. Assoc.) 274:529-530. doi:10.1001/jama.1995.03530070027011.

31. Chase-Topping, M. E., T. Rosser, L. J. Allison, E. Courcier, J. Evans, I. J. McKendrick, M. C. Pearce, I. Handel, A. Caprioli, H. Karch, M. F. Hanson, K. G. J. Pollock, M. E. Locking, M. E. J. Woolhouse, L. Matthews, J. C. Low, and D. L. Gally. 2012. Pathogenic potential to humans of bovine Escherichia coli O26,
Scotland. Emerg. Infect. Dis. 18:439-448. doi:10.3201/eid1803. 111236.

32. de Boer, R. F., M. Ferdous, A. Ott, H. R. Scheper, G. J. Wisselink, M. E. Heck, J. W. Rossen, and A. M. D. Kooistra-Smid. 2015. Assessing the public health risk of Shiga toxin-producing Escherichia coli by use of a rapid diagnostic screening algorithm. J. Clin. Microbiol. 53:1588-1598. doi:10.1128/JCM.03590-14.

33. Delannoy, S., P. Mariani-Kurkdjian, S. Bonacorsi, S. Liguori, and P. Fach. 2015. Characteristics of emerging human-pathogenic Escherichia coli O26:H11 strains isolated in France between 2010 and 2013 and carrying the stx $_{2 \mathrm{~d}}$ gene only. J. Clin. Microbiol. 53:486492 doi:10.1128/JCM.02290-14.

34. Díaz, S., D. Vidal, S. Herrera-León, and S. Sánchez. 2011. Sorbitol-fermenting, $\beta$-glucuronidase-positive, Shiga toxin-negative Escherichia coli $\mathrm{O} 157: \mathrm{H} 7$ in free-ranging red deer in southcentral Spain. Foodborne Pathog. Dis. 8:1313-1315. doi:10.1089/ fpd.2011.0923.

35. Donohue-Rolfe, A., I. Kondova, S. Oswald, D. Hutto, and S. Tzipori. 2000. Escherichia coli O157:H7 strains that express Shiga toxin (Stx) 2 alone are more neurotropic for gnotobiotic piglets than are isotypes producing only Stx1 or both Stx1 and Stx2. J. Infect. Dis. 181:1825-1829. doi:10.1086/315421.

36. Dytoc, M. T., A. Ismaili, D. J. Philpott, R. Soni, J. L. Brunton, and P. M. Sherman. 1994. Distinct binding properties of eaeA-negative verocytotoxin-producing Escherichia coli of serotype O113:H21. Infect. Immun. 62:3494-3505.

37. EFSA Panel on Biological Hazards. 2013. Scientific opinion on VTEC-seropathotype and scientific criteria regarding pathogenicity assessment. EFSA J. 11:3138. doi:10.2903/j.efsa.2013.3138.

38. EFSA Panel on Biological Hazards. 2015. Public health risks associated with enteroaggregative Escherichia coli (EAEC) as a food-borne pathogen. EFSA J. 13:4330. doi:10.2903/j.efsa.2015. 4330.

39. Eklund, M., M. Bielaszewska, U. M. Nakari, H. Karch, and A. Siitonen. 2006. Molecular and phenotypic profiling of sorbitolfermenting Escherichia coli $\mathrm{O} 157: \mathrm{H}^{-}$human isolates from Finland. Clin. Microbiol. Infect. 12:634-641. doi:10.1111/j.1469-0691.2006. 01478.x.

40. Ethelberg, S., K. E. P. Olsen, F. Scheutz, C. Jensen, P. Schiellerup, J. Engberg, A. M. Petersen, B. Olesen, P. Gerner-Smidt, and K. Mølbak. 2004. Virulence factors for hemolytic uremic syndrome, Denmark. Emerg. Infect. Dis. 10:842-847. doi:10.3201/eid1005. 030576.

41. Fasel, D., A. Mellmann, N. Cernela, H. Hächler, A. Fruth, N. Khanna, A. Egli, C. Beckmann, H. H. Hirsch, D. Goldenberger, and R. Stephan. 2014. Hemolytic uremic syndrome in a 65-year-old male linked to a very unusual type of $s t x_{2 \mathrm{e}^{-}}$and eae-harboring O51:H49 Shiga toxin-producing Escherichia coli. J. Clin. Microbiol. 52:1301-1303. doi:10.1128/JCM.03459-13.

42. Feng, P. C. H., S. Delannoy, D. W. Lacher, J. M. Bosilevac, P. Fach, and L. Beutin. 2017. Shiga toxin-producing serogroup O91 Escherichia coli strains isolated from food and environmental samples. Appl. Environ. Microbiol. 83:18 e01231-17. doi:10.1128/ AEM.01231-17.

43. Feng, P. C. H., S. Delannoy, D. W. Lacher, L. F. dos Santos, L. Beutin, P. Fach, M. Rivas, E. L. Hartland, A. W. Paton, and B. E. C. Guth. 2014. Genetic diversity and virulence potential of Shiga toxinproducing Escherichia coli O113:H21 strains isolated from clinical, environmental, and food sources. Appl. Environ. Microbiol. 80:4757-4763. doi:10.1128/AEM.01182-14.

44. Feng, P. C. H., S. R. Monday, D. W. Lacher, L. Allison, A. Siitonen, C. Keys, M. Eklund, H. Nagano, H. Karch, J. Keen, and T. S. Whittam. 2007. Genetic diversity among clonal lineages within Escherichia coli O157:H7 stepwise evolutionary model. Emerg. Infect. Dis. 13:1701-1706. doi:10.3201/eid1311.070381.

45. Feng, P. C. H., and S. Reddy. 2013. Prevalence of Shiga toxin subtypes and selected other virulence factors among Shiga-toxigenic Escherichia coli strains isolated from fresh produce. Appl. Environ. Microbiol. 79:6917-6923. doi:10.1128/AEM.02455-13. 
46. Feng, P. C. H., and S. P. Reddy. 2014. Prevalence and diversity of enterotoxigenic Escherichia coli strains in fresh produce. J. Food Prot. 77:820-823. doi:10.4315/0362-028X.JFP-13-412.

47. Fierz, L., N. Cernela, E. Hauser, M. Nüesch-Inderbinen, and R. Stephan. 2017. Characteristics of Shigatoxin-producing Escherichia coli strains isolated during 2010-2014 from human infections in Switzerland. Front. Microbiol. 8:1471. doi:10.3389/fmicb.2017. 01471.

48. Frank, C., M. Faber, M. Askar, H. Bernard, A. Fruth, A. Gilsdorf, M. Höhle, H. Karch, G. Krause, R. Prager, A. Spode, K. Stark, and D. Werber. 2011. Large and ongoing outbreak of haemolytic uraemic syndrome, Germany, May 2011. Euro. Surveill. 16(21):pii=19878.

49. Franz, E., A. H. van Hoek, M. Wuite, F. J. van der Wal, A. G. de Boer, E. I. Bouw, and H. J. Aarts. 2015. Molecular hazard identification of non-O157 Shiga toxin-producing Escherichia coli (STEC). PLoS One 10:e0120353. doi:10.1371/journal.pone. 0120353.

50. Friedrich, A. W., M. Bielaszewska, W.-L. Zhang, M. Pulz, T. Kuczius, A. Ammon, and H. Karch. 2002. Escherichia coli harboring Shiga toxin 2 gene variants: frequency and association with clinical symptoms. J. Infect. Dis. 185:74-84. doi:10.1086/ 338115 .

51. Friedrich, A. W., J. Borell, M. Bielaszewska, A. Fruth, H. Tschäpe, and H. Karch. 2003. Shiga toxin 1c-producing Escherichia coli strains: phenotypic and genetic characterization and association with human disease. J. Clin. Microbiol. 41:2448-2453. doi:10.1128/ JCM.41.6.2448-2453.2003.

52. Friedrich, A. W., K. V. Nierhoff, M. Bielaszewska, A. Mellmann, and H. Karch. 2004. Phylogeny, clinical associations, and diagnostic utility of the pilin subunit gene $(s f p A)$ of sorbitol-fermenting, enterohemorrhagic Escherichia coli $\mathrm{O} 157: \mathrm{H}^{-}$. J. Clin. Microbiol. 42:4697-4701. doi:10.1128/JCM.42.10.4697-4701.2004.

53. Friesema, I., K. van der Zwaluw, T. Schuurman, M. Kooistra-Smid, E. Franz, Y. van Duynhoven, and W. van Pelt. 2014. Emergence of Escherichia coli encoding Shiga toxin $2 \mathrm{f}$ in human Shiga toxinproducing E. coli (STEC) infections in the Netherlands, January 2008 to December 2011. Euro. Surveill. 19(17):26-32. doi:10.2807/ 1560-7917.ES2014.19.17.20787.

54. Friesema, I. H. M., M. G. Keijzer-Veen, M. Koppejan, H. S. Schipper, A. J. van Griethuysen, M. E. O. C. Heck, and W. van Pelt. 2015. Hemolytic uremic syndrome associated with Escherichia coli O8:H19 and Shiga toxin 2f gene. Emerg. Infect. Dis. 21:168-169. doi:10.3201/eid2101.140515.

55. Fuller, C. A., C. A. Pellino, M. J. Flagler, J. E. Strasser, and A. A. Weiss. 2011. Shiga toxin subtypes display dramatic differences in potency. Infect. Immun. 79:1329-1337. doi:10.1128/IAI.01182-10.

56. Gannon, V. P., C. Teerling, S. A. Masri, and C. L. Gyles. 1990. Molecular cloning and nucleotide sequence of another variant of the Escherichia coli Shiga-like toxin II family. J. Gen. Microbiol. 136:1125-1135.

57. García-Aljaro, C., M. Muniesa, J. Jofre, and A. R. Blanch. 2006. Newly identified bacteriophage carrying the $s t x_{2 g}$ Shiga toxin gene isolated from Escherichia coli strains in polluted waters. FEMS Microbiol. Lett. 258:127-135. doi:10.1111/j.1574-6968.2006. 00213.x.

58. Gerber, A., H. Karch, F. Allerberger, H. M. Verweyen, and L. B. Zimmerhackl. 2002. Clinical course and the role of Shiga toxinproducing Escherichia coli infection in the hemolytic-uremic syndrome in pediatric patients, 1997-2000, in Germany and Austria: a prospective study. J. Infect. Dis. 186:493-500. doi:10.1086/ 341940 .

59. Gill, A., and G. Huszczynski. 2016. Enumeration of Escherichia coli O157:H7 in outbreak-associated beef patties. J. Food Prot. 79:12661268. doi:10.4315/0362-028X.JFP-15-521.

60. Gill, A., and D. Oudit. 2015. Enumeration of Escherichia coli 0157 in outbreak-associated gouda cheese made with raw milk. J. Food Prot. 78:1733-1737. doi:10.4315/0362-028X.JFP-15-036.

61. Goswami, K., C. Chen, L. Xiaoli, K. A. Eaton, and E. G. Dudley. 2015. Coculture of Escherichia coli O157:H7 with a non-pathogenic
E. coli strain increases toxin production and virulence in a germfree mouse model. Infect. Immun. 83:4185-4193. doi:10.1128/IAI. 00663-15.

62. Gould, L. H., R. K. Mody, K. L. Ong, P. Clogher, A. B. Cronquist, K. N. Garman, S. Lathrop, C. Medus, N. L. Spina, T. H. Webb, P. L. White, K. Wymore, R. E. Gierke, B. E. Mahon, P. M. Griffin, and Emerging Infections Program FoodNet Working Group. 2013. Increased recognition of non-O157 Shiga toxin-producing Escherichia coli infections in the United States during 2000-2010: epidemiologic features and comparison with $E$. coli $\mathrm{O} 157$ infections. Foodborne Pathog. Dis. 10:453-460. doi:10.1089/fpd.2012.1401.

63. Grande, L., V. Michelacci, R. Bondì, F. Gigliucci, E. Franz, M. A. Badouei, S. Schlager, F. Minelli, R. Tozzoli, A. Caprioli, and S. Morabito. 2016. Whole-genome characterization and strain comparison of VT2f-producing Escherichia coli causing hemolytic uremic syndrome. Emerg. Infect. Dis. 22:2078-2086. doi:10.3201/eid2212. 160017.

64. Grotiuz, G., A. Sirok, P. Gadea, G. Varela, and F. Schelotto. 2006. Shiga toxin 2-producing Acinetobacter haemolyticus associated with a case of bloody diarrhea. J. Clin. Microbiol. 44:3838-3841. doi:10.1128/JCM.00407-06.

65. Hara-Kudo, Y., and K. Takatori. 2011. Contamination level and ingestion dose of foodborne pathogens associated with infections. Epidemiol. Infect. 139:1505-1510. doi:10.1017/S095026881000292X.

66. Havelaar, A. H., and A. N. Swart. 2014. Impact of acquired immunity and dose-dependent probability of illness on quantitative microbial risk assessment. Risk Anal. 34:1807-1819. doi:10.1111/ risa. 12214.

67. Hayashi, T., K. Makino, M. Ohnishi, K. Kurokawa, K. Ishii, K. Yokoyama, C. G. Han, E. Ohtsubo, K. Nakayama, T. Murata, M. Tanaka, T. Tobe, T. Iida, H. Takami, T. Honda, C. Sasakawa, N. Ogasawara, T. Yasunaga, S. Kuhara, T. Shiba, M. Hattori, and H. Shinagawa. 2001. Complete genome sequence of enterohemorrhagic Escherichia coli $\mathrm{O} 157: \mathrm{H} 7$ and genomic comparison with a laboratory strain K-12. DNA Res. 8:11-22. doi:10.1093/dnares/8.1.11.

68. Hedican, E. B., C. Medus, J. M. Besser, B. A. Juni, B. Koziol, C. Taylor, and K. E. Smith. 2009. Characteristics of O157 versus nonO157 Shiga toxin-producing Escherichia coli infections in Minnesota, 2000-2006. Clin. Infect. Dis. 49:358-364. doi:10.1086/ 600302.

69. Herold, S., H. Karch, and H. Schmidt. 2004. Shiga toxin-encoding bacteriophages-genomes in motion. Int. J. Med. Microbiol. 294:115-121. doi:10.1016/j.ijmm.2004.06.023.

70. Herold, S., J. C. Paton, and A. W. Paton. 2009. Sab, a novel autotransporter of locus of enterocyte effacement-negative Shigatoxigenic Escherichia coli O113:H21 contributes to adherence and biofilm formation. Infect. Immun. 77:3234-3243. doi:10.1128/IAI. 00031-09.

71. Hofer, E., N. Cernela, and R. Stephan. 2012. Shiga toxin subtypes associated with Shiga toxin-producing Escherichia coli strains isolated from red deer, roe deer, chamois, and ibex. Foodborne Pathog. Dis. 9:792-795. doi:10.1089/fpd.2012.1156.

72. Horcajo, P., G. Domínguez-Bernal, R. de la Fuente, J. A. RuizSanta-Quiteria, J. E. Blanco, M. Blanco, A. Mora, G. Dahbi, C. López, B. Puentes, M. P. Alonso, J. Blanco, and J. A. Orden. 2012. Comparison of ruminant and human attaching and effacing Escherichia coli (AEEC) strains. Vet. Microbiol. 155:341-348. doi:10.1016/j.vetmic.2011.08.034.

73. Imamovic, L., and M. Muniesa. 2011. Quantification and evaluation of infectivity of Shiga toxin-encoding bacteriophages in beef and salad. Appl. Environ. Microbiol. 77: 3536-3540. doi:10.1128/AEM. 02703-10.

74. Imamovic, L., R. Tozzoli, V. Michelacci, F. Minelli, M. L. Marziano, A. Caprioli, and S. Morabito. 2010. OI-57, a genomic island of Escherichia coli O157, is present in other seropathotypes of Shiga toxin-producing $E$. coli associated with severe human disease. Infect. Immun. 78:4697-4704. doi:10.1128/IAI.00512-10.

75. Inward, C. D., D. V. Millford, and C. M. Taylor. 1993. Differing outcomes of Escherichia coli O157 colitis in identical twins. Pediatr. Nephrol. 7:771-772. doi:10.1007/BF01213351. 
76. Isiko, J., M. Khaitsa, and T. M. Bergholz. 2015. Novel sequence types of non-O157 Shiga toxin-producing Escherichia coli isolated from cattle. Lett. Appl. Microbiol. 60:552-557. doi:10.1111/lam. 12404.

77. Johnson, K. E., C. M. Thorpe, and C. L. Sears. 2006. The emerging clinical importance of non-O157 Shiga toxin-producing Escherichia coli. Clin. Infect. Dis. 43:1587-1595.

78. Kaper, J. B., J. P. Nataro, and H. L. T. Mobley. 2004. Pathogenic Escherichia coli. Nat. Rev. Microbiol. 2:123-140. doi:10.1038/ nrmicro818.

79. Käppeli, U., H. Hächler, N. Giezendanner, L. Beutin, and R. Stephan. 2011. Human infections with non-O157 Shiga toxinproducing Escherichia coli, Switzerland, 2000-2009. Emerg. Infect. Dis. 17:180-185. doi:10.3201/eid1702.100909.

80. Karch, H., and M. Bielaszewska. 2001. Sorbitol-fermenting Shiga toxin-producing Escherichia coli $\mathrm{O} 157: \mathrm{H}^{-}$strains: epidemiology, phenotypic and molecular characteristics, and microbiological diagnosis. J. Clin. Microbiol. 39:2043-2049. doi:10.1128/JCM.39. 6.2043-2049.2001

81. Karch, H., T. Meyer, H. Rüssmann, and J. Heesemann. 1992. Frequent loss of Shiga-like toxin genes in clinical isolates of Escherichia coli upon subcultivation. Infect. Immun. 60:3464-3467.

82. Karmali, M. A., M. Mascarenhas, S. Shen, K. Ziebell, S. Johnson, R. Reid-Smith, J. Isaac-Renton, C. Clark, K. Rahn, and J. B. Kaper. 2003. Association of genomic O island 122 of Escherichia coli EDL 933 with verocytotoxin-producing $E$. coli seropathotypes that are linked to epidemic and/or serious disease. J. Clin. Microbiol. 41:4930-4940. doi:10.1128/JCM.41.11.4930-4940.2003.

83. Karmali, M. A., M. Petrie, C. Lim, P. C. Flemming, G. S. Arbus, and H. Lior. 1985. The association between idiopathic hemolytic uremic syndrome and infection by verocytotoxin-producing Escherichia coli. J Infect. Dis. 151:775-782.

84. Khalil, R. S. K., C. Skinner, S. Patfield, and X. He. 2016. Phagemediated Shiga toxin (Stx) horizontal gene transfer and expression in non-Shiga toxigenic Enterobacter and Escherichia coli strains Pathog. Dis. 74(5):pii=ftw037. doi:10.1093/femspd/ftw037.

85. Klapproth, J. M. A., and F. Meyer. 2009. [Multitalented lymphostatin]. Dtsch. Med. Wochenschr. 134:417-420. doi:10.1055/s-00291208066.

86. Klapproth, J. M. A., I. C. A. Scaletsky, B. P. McNamara, L. C. Lai, C. Malstrom, S. P. James, and M. S. Donnenberg. 2000. A large toxin from pathogenic Escherichia coli strains that inhibits lymphocyte activation. Infect. Immun. 68:2148-2155. doi:10.1128/ IAI.68.4.2148-2155.2000.

87. Konczy, P., K. Ziebell, M. Mascarenhas, A. Choi, C. Michaud, A. M. Kropinski, T. S. Whittam, M. Wickham, B. Finlay, and M. A Karmali. 2008. Genomic O island 122, locus for enterocyte effacement, and the evolution of virulent verocytotoxin-producing Escherichia coli. J. Bacteriol. 190:5832-5840. doi:10.1128/JB. 00480-08.

88. Lacher, D. W., J. Gangiredla, I. Patel, C. A. Elkins, and P. C. H. Feng. 2016. Use of the Escherichia coli identification microarray for characterizing the health risks of Shiga toxin-producing E. coli isolated from foods. J. Food Prot. 79:1656-1662. doi:10.43150362-028X.JFP16-176

89. Lacher, D. W., H. Steinsland, and T. S. Whittam. 2006. Allelic subtyping of the intimin locus (eae) of pathogenic Escherichia col by fluorescent RFLP. FEMS Microbiol. Lett. 261:80-87. doi:10. 1111/j.1574-6968.2006.00328.x

90. Lee, J. H., and S. J. Choi. 2006. Isolation and characteristics of sorbitol-fermenting Escherichia coli O157 strains from cattle. Microbes Infect. 8:2021-2026. doi:10.1016/j.micinf.2006.03.002.

91. Lienemann, T., E. Salo, R. Rimhanen-Finne, K. Rönnholm, M. Taimisto, J. J. Hirvonen, E. Tarkka, M. Kuusi, and A. Siitonen. 2012. Shiga toxin-producing Escherichia coli serotype $\mathrm{O} 78: \mathrm{H}^{-}$in family, Finland, 2009. Emerg. Infect. Dis. 18:577-581. doi:10.3201/ eid1804.111310.

92. Liptáková, A., L. Siegfried, M. Kmetova, E. Birosová, D. Kotulová, A. Bencátová, M. Kosecká, and P. Banovčin. 2005. Hemolytic uremic syndrome caused by verotoxin-producing Escherichia coli O26. Folia Microbiol. (Praha) 50:95-98. doi:10.1007/BF0293145.

93. Luna-Gierke, R. E., K. Wymore, J. Sadlowski, P. Clogher, R. W. Gierke, M. Tobin-D’Angelo, A. Palmer, C. Medus, C. Nicholson, S. McGuire, H. Martin, K. Garman, P. M. Griffin, and R. K. Mody. 2014. Multiple-aetiology enteric infections involving non-O157 Shiga toxin-producing Escherichia coli-FoodNet, 2001-2010. Zoonoses Public Health 61:492-498. doi:10.1111/zph.12098.

94. Marejková, M., K. Bláhová, J. Janda, A. Fruth, and P. Petráš. 2013. Enterohemorrhagic Escherichia coli as causes of hemolytic uremic syndrome in the Czech Republic. PLoS One 8:e73927. doi:10.1371/ journal.pone.0073927.

95. Mariani-Kurkdjian, P., C. Lemaitre, P. Bidet, D. Perez, L. Boggini, T. Kwon, and S. Bonacorsi. 2014. Haemolytic-uraemic syndrome with bacteraemia caused by a new hybrid Escherichia coli pathotype. New Microbes New Infect. 2:127-131. doi:10.1002/ nmi2.49.

96. Martin, A., and L. Beutin. 2011. Characteristics of Shiga toxinproducing Escherichia coli from meat and milk products of different origins and association with food producing animals as main contamination sources. Int. J. Food Microbiol. 146:99-104. doi:10. 1016/j.ijfoodmicro.2011.01.041

97. Martinez-Castillo, A., P. Quirós, F. Navarro, E. Miró, and M. Muniesa. 2013. Shiga toxin 2-encoding bacteriophages in human fecal samples from healthy individuals. Appl. Environ. Microbiol. 79:4862-4868. doi:10.1128/AEM.01158-13.

98. McFarland, N., N. Bundle, C. Jenkins, G. Godbole, A. Mikhail, T. Dallman, C. O’Connor, N. D. McCarthy, E. O’Connell, J. Treacy, G. Dabkei, J. Mapstone, Y. Landy, J. Moore, R. Partridge, F. Jorgensen, C. Willis, P. Mook, C. Rawlings, R. Acornley, C. Featherstone, S. Gayle, J. Edge, E. McNamara, J. Hawker, and S. Balasegaram. 2017. Recurrent seasonal outbreak of an emerging serotype of Shiga-toxin producing Escherichia coli (STEC O55:H7 Stx2a) in the south west of England, July 2014 to September 2015. Euro Surveill. 22(36):pii=30610. doi:10.2807/1560-7917.ES.2017. 22.36.30610

99. Mellmann, A., M. Bielaszewska, R. Köck, A. W. Friedrich, A. Fruth, B. Middendorf, D. Harmsen, M. A. Schmidt, and H. Karch. 2008. Analysis of collection of hemolytic uremic syndromeassociated enterohemorrhagic Escherichia coli. Emerg. Infect. Dis. 14:1287-1290. doi:10.3201/eid1408.071082.

100. Mellmann, A., A. Fruth, A. W. Friedrich, L. H. Wieler, D. Harmsen, D. Weber, B. Middendorf, M. Bielaszewska, and H. Karch. 2009 Phylogeny and disease association of Shiga toxin-producing Escherichia coli 091. Emerg. Infect. Dis. 15:1474-1477. doi:10. 3201/eid1509.090161

101. Mellor, G. E., T. E. Besser, M. A. Davis, B. Beavis, W. K. Jung, H. V. Smith, A. V. Jennison, C. J. Doyle, P. S. Chandry, K. S. Gobius, and N. Fegan. 2013. Multilocus genotype analysis of Escherichia coli $\mathrm{O} 157$ isolates from Australia and the United States provides evidence of geographic divergence. Appl. Environ. Microbiol. 79:5050-5058. doi:10.1128/AEM.01525-13.

102. Melton-Celsa, A. R., S. C. Darnell, and A. D. O'Brien. 1996. Activation of Shiga-like toxins by mouse and human intestinal mucus correlates with virulence of enterohemorrhagic Escherichia coli $\mathrm{O} 91: \mathrm{H} 21$ isolates in orally infected, streptomycin-treated mice. Infect. Immun. 64:1569-1576.

103. Monaghan, A., B. Byrne, S. Fanning, T. Sweeney, D. McDowell, and D. J. Bolton. 2011. Serotypes and virulence profiles of nonO157 Shiga toxin-producing Escherichia coli isolates from bovine farms. Appl. Environ. Microbiol. 77:8662-8668. doi:10.1128/AEM. 06190-11.

104. Montero, D. A., J. Velasco, C. F. Del, J. L. Puente, N. L. Padola, D. A. Rasko, M. Farfan, J. C. Salazar, and R. Vidal. 2017. Locus of adhesion and autoaggregation (LAA), a pathogenicity island present in emerging Shiga toxin-producing Escherichia coli strains. Sci. Rep. 7:7011. doi:10.1038/s41598-017-06999-y.

105. Mora, A., A. Herrrera, C. López, G. Dahbi, R. Mamani, J. M. Pita, M. P. Alonso, J. Llovo, M. I. Bernárdez, J. E. Blanco, M. Blanco, and J. Blanco. 2011. Characteristics of Shiga-toxin-producing 
enteroaggregative Escherichia coli O104:H4 German outbreak strain and STEC strains isolated in Spain. Int. Microbiol. 14:121-141. doi:10.2436/20.1501.01.142.

106. Mora, A., C. López, G. Dhabi, A. M. López-Beceiro, L. E. Fidalgo, E. A. Díaz, C. Martínez-Carrasco, R. Mamani, A. Herrera, J. E. Blanco, M. Blanco, and J. Blanco. 2012. Sero pathotypes, phylogroups, Stx subtypes, and intimin types of wildlife-carried, Shiga toxin-producing Escherichia coli strains with the same characteristics as human-pathogenic isolates. Appl. Environ. Microbiol. 78:2578-2585. doi:10.1128/AEM.07520-11.

107. Morabito, S., R. Tozzoli, E. Oswald, and A. Caprioli. 2003. A mosaic pathogenicity island made up of the locus of enterocyte effacement and a pathogenicity island of Escherichia coli O157:H7 is frequently present in attaching and effacing E. coli. Infect. Immun. 71:3343-3348. doi:10.1128/IAI.71.6.3343-3348.2003.

108. Morton, V., J. M. Cheng, D. Sharma, and A. Kearney. 2017. Notes from the field: outbreak of Shiga toxin-producing Escherichia coli O121 infections associated with flour-Canada, 2016-2017. Morb. Mortal. Wkly. Rep. 66:705-706. doi:10.15585/mmwr.mm6626a6.

109. Muniesa, M., and J. Jofre. 2004. Abundance in sewage of bacteriophages infecting Escherichia coli O157:H7. Methods Mol. Biol. 268:79-88. doi:10.1385/1-59259-766-1:079.

110. Naseer, U., I. Løbersli, M. Hindrum, T. Bruvik, and L. T. Brandal. 2017. Virulence factors of Shiga toxin-producing Escherichia coli and the risk of developing haemolytic uraemic syndrome in Norway, 1992-2013. Eur. J. Clin. Microbiol. Infect. Dis. 36:1613-1620. doi:10.1007/s10096-017-2974-z.

111. Neupane, M., G. S. Abu-Ali, A. Mitra, D. W. Lacher, S. D. Manning, and J. T. Riordan. 2011. Shiga toxin 2 overexpression in Escherichia coli $\mathrm{O} 157: \mathrm{H} 7$ strains associated with severe human disease. Microb. Pathog. 51:466-470. doi:10.1016/j.micpath.2011. 07.009 .

112. Newton, H. J., J. Sloan, D. M. Bulach, T. Seemann, C. C. Allison, M. Tauschek, R. M. Robins-Browne, J. C. Paton, T. S. Whittam, A. W. Paton, and E. L. Hartland. 2009. Shiga toxin-producing Escherichia coli strains negative for locus of enterocyte effacement. Emerg. Infect. Dis. 15:372-380. doi:10.3201/eid1502.080631.

113. Nicholls, L., T. H. Grant, and R. M. Robins-Browne. 2000. Identification of a novel genetic locus that is required for in vitro adhesion of a clinical isolate of enterohaemorrhagic Escherichia coli to epithelial cells. Mol. Microbiol. 35:275-288. doi:10.1046/j.13652958.2000.01690.x.

114. Nyholm, O., S. Heinikainen, S. Pelkonen, S. Hallanvuo, K. Haukka, and A. Siitonen. 2015. Hybrids of Shigatoxigenic and enterotoxigenic Escherichia coli (STEC/ETEC) among human and animal isolates in Finland. Zoonoses Public Health 62:518-524. doi:10. 1111/zph.12177.

115. Ogura, Y., S. I. Mondal, M. R. Islam, T. Mako, K. Arisawa, K. Katsura, T. Ooka, Y. Gotoh, K. Murase, M. Ohnishi, and T. Hayashi. 2015. The Shiga toxin 2 production level in enterohemorrhagic Escherichia coli $\mathrm{O} 157: \mathrm{H} 7$ is correlated with the subtypes of toxin-encoding phage. Sci. Rep. 5:16663. doi:10.1038/ srep16663.

116. Oh, K. H., E. Shin, S. M. Jung, J. Im, S. H. Cho, S. Hong, C. K. Yoo, and G. T. Chung. 2017. First isolation of a hybrid Shigatoxigenic and enterotoxigenic Escherichia coli strain harboring the $s_{1} x_{2}$ and elt genes in Korea. Jpn. J. Infect. Dis. 70:347-348. doi:10.7883/yoken.JJID.2016.237.

117. Ooka, T., K. Seto, K. Kawano, H. Kobayashi, Y. Etoh, S. Ichihara, A. Kaneko, J. Isobe, K. Yamaguchi, K. Horikawa, T. A. Gomes, A. Linden, M. Bardiau, J. G. Mainil, L. Beutin, Y. Ogura, and T. Hayashi. 2012. Clinical significance of Escherichia albertii. Emerg. Infect. Dis. 18:488-492. doi:10.3201/eid1803.111401.

118. Ooka, T., E. Tokuoka, M. Furukawa, T. Nagamura, Y. Ogura, K. Arisawa, S. Harada, and T. Hayashi. 2013. Human gastroenteritis outbreak associated with Escherichia albertii, Japan. Emerg. Infect. Dis. 19:144-146. doi:10.3201/eid1901.120646.

119. Paciorek, J. 2002. Virulence properties of Escherichia coli faecal strains isolated in Poland from healthy children and strains belonging to serogroups $\mathrm{O} 18, \mathrm{O} 26, \mathrm{O} 44, \mathrm{O} 86, \mathrm{O} 126$ and $\mathrm{O} 127$ isolated from children with diarrhoea. J. Med. Microbiol. 51:548556. doi:10.1099/0022-1317-51-7-548.

120. Paton, A. W., R. M. Ratcliff, R. M. Doyle, J. Seymour-Murray, D. Davos, J. A. Lanser, and J. C. Paton. 1996. Molecular microbiological investigation of an outbreak of hemolytic-uremic syndrome caused by dry fermented sausage contaminated with Shiga-like toxin-producing Escherichia coli. J. Clin. Microbiol. 34:1622-1627.

121. Paton, A. W., P. Srimanote, M. C. Woodrow, and J. C. Paton. 2001. Characterization of Saa, a novel autoagglutinating adhesin produced by locus of enterocyte effacement-negative Shiga-toxigenic Escherichia coli strains that are virulent for humans. Infect. Immun. 69:6999-7009. doi:10.1128/IAI.69.11.6999-7009.2001.

122. Paton, A. W., M. C. Woodrow, R. M. Doyle, J. A. Lanser, and J. C. Paton. 1999. Molecular characterization of a Shiga toxigenic Escherichia coli O113:H21 strain lacking eae responsible for a cluster of cases of hemolytic-uremic syndrome. J. Clin. Microbiol. 37:3357-3361.

123. Perna, N. T., G. Plunkett, V. Burland, B. Mau, J. D. Glasner, D. J. Rose, G. F. Mayhew, P. S. Evans, J. Gregor, H. A. Kirkpatrick, G. Pósfai, J. Hackett, S. Klink, A. Boutin, Y. Shao, L. Miller, E. J. Grotbeck, N. W. Davis, A. Lim, E. T. Dimalanta, K. D. Potamousis, J. Apodaca, T. S. Anantharaman, J. Lin, G. Yen, D. C. Schwartz, R. A. Welch, and F. R. Blattner. 2001. Genome sequence of enterohaemorrhagic Escherichia coli O157:H7. Nature 409:529533.

124. Persson, S., K. E. P. Olsen, S. Ethelberg, and F. Scheutz. 2007. Subtyping method for Escherichia coli Shiga toxin (verocytotoxin) 2 variants and correlations to clinical manifestations. J. Clin. Microbiol. 45:2020-2024. doi:10.1128/JCM.02591-06.

125. Prager, R., A. Fruth, U. Busch, and E. Tietze. 2011. Comparative analysis of virulence genes, genetic diversity and phylogeny of Shiga toxin $2 \mathrm{~g}$ and heat-stable enterotoxin STIa encoding Escherichia coli isolates from humans, animals, and environmental sources. Int. J. Med. Microbiol. 301:181-191. doi:10.1016/j.ijmm. 2010.06.003.

126. Prager, R., A. Fruth, U. Siewert, U. Strutz, and H. Tschäpe. 2009. Escherichia coli encoding Shiga toxin $2 \mathrm{f}$ as an emerging human pathogen. Int. J. Med. Microbiol. 299:343-353. doi:10.1016/j.ijmm. 2008.10.008.

127. Preussel, K., M. Höhle, K. Stark, and D. Werber. 2013. Shiga toxinproducing Escherichia coli $\mathrm{O} 157$ is more likely to lead to hospitalization and death than non-O157 serogroups-except O104. PLoS One 8:e78180. doi:10.1371/journal.pone.0078180.

128. Probert, W. S., C. McQuaid, and K. Schrader. 2014. Isolation and identification of an Enterobacter cloacae strain producing a novel subtype of Shiga toxin type 1. J. Clin. Microbiol. 52:2346-2351. doi:10.1128/JCM.00338-14.

129. Quirós, P., A. Martínez-Castillo, and M. Muniesa. 2015. Improving detection of Shiga toxin-producing Escherichia coli by molecular methods by reducing the interference of free Shiga toxin-encoding bacteriophages. Appl. Environ. Microbiol. 81:415-421. doi:10.1128/ AEM.02941-14.

130. Rasko, D. A., D. R. Webster, J. W. Sahl, A. Bashir, N. Boisen, F. Scheutz, E. E. Paxinos, R. Sebra, C. S. Chin, D. Iliopoulos, A. Klammer, P. Peluso, L. Lee, A. O. Kislyuk, J. Bullard, A. Kasarskis, S. Wang, J. Eid, D. Rank, J. C. Redman, S. R. Steyert, J. FrimodtMøller, C. Struve, A. M. Petersen, K. A. Krogfelt, J. P. Nataro, E. E. Schadt, and M. K. Waldor. 2011. Origins of the E. coli strain causing an outbreak of hemolytic-uremic syndrome in Germany. N. Engl. J. Med. 365:709-717. doi:10.1056/NEJMoa1106920.

131. Rivas, M., E. Miliwebsky, I. Chinen, C. D. Roldán, L. Balbi, B. García, G. Fiorilli, S. Sosa-Estani, J. Kincaid, J. Rangel, P. M. Griffin, and the Case-Control Study Group. 2006. Characterization and epidemiologic subtyping of Shiga toxin-producing Escherichia coli strains isolated from hemolytic uremic syndrome and diarrhea cases in Argentina. Foodborne Pathog. Dis. 3:88-96. doi:10.1089/ fpd.2006.3.88.

132. Rosser, T., T. Dransfield, L. Allison, M. Hanson, N. Holden, J. Evans, S. Naylor, R. La Ragione, J. C. Low, and D. L. Gally. 2008. Pathogenic potential of emergent sorbitol-fermenting Escherichia 
coli O157:NM. Infect. Immun. 76:5598-5607. doi:10.1128/IAI. 01180-08.

133. Russo, L. M., N. F. Abdeltawab, A. D. O'Brien, M. Kotb, and A. R. Melton-Celsa. 2015. Mapping of genetic loci that modulate differential colonization by Escherichia coli O157:H7 TUV86-2 in advanced recombinant inbred BXD mice. BMC Genomics 16:947. doi:10.1186/s12864-015-2127-7.

134. Sallam, K. I., M. A. Mohammed, A. M. Ahdy, and T. Tamura. 2013. Prevalence, genetic characterization and virulence genes of sorbitolfermenting Escherichia coli $\mathrm{O} 157: \mathrm{H}^{-}$and E. coli $\mathrm{O} 157: \mathrm{H} 7$ isolated from retail beef. Int. J. Food Microbiol. 165:295-301. doi:10.1016/j. ijfoodmicro.2013.05.024.

135. Sánchez, S., M. T. Llorente, L. Herrera-León, R. Ramiro, S. Nebreda, M. A. Remacha, and S. Herrera-León. 2017. Mucusactivatable Shiga toxin genotype st $x_{2 \mathrm{~d}}$ in Escherichia coli $\mathrm{O} 157: \mathrm{H} 7$ Emerg. Infect. Dis. 23:1431-1433. doi:10.3201/eid2308.170570.

136. Scheutz, F. 2014. Taxonomy meets public health: the case of Shiga toxin-producing Escherichia coli. Microbiol. Spectr. 2. doi:10.1128/ microbiolspec.EHEC-0019-2013.

137. Scheutz, F., L. D. Teel, L. Beutin, D. Piérard, G. Buvens, H. Karch, A. Mellmann, A. Caprioli, R. Tozzoli, S. Morabito, N. A. Strockbine, A. R. Melton-Celsa, M. Sanchez, S. Persson, and A. D. O'Brien. 2012. Multicenter evaluation of a sequence-based protocol for subtyping Shiga toxins and standardizing Stx nomenclature. J. Clin. Microbiol. 50:2951-2963. doi:10.1128/ JCM.00860-12.

138. Schmidt, H., J. Scheef, H. I. Huppertz, M. Frosch, and H. Karch. 1999. Escherichia coli $\mathrm{O} 157: \mathrm{H} 7$ and $\mathrm{O} 157: \mathrm{H}^{-}$strains that do not produce Shiga toxin: phenotypic and genetic characterization of isolates associated with diarrhea and hemolytic-uremic syndrome. $J$. Clin. Microbiol. 37:3491-3496.

139. Schmidt, H., J. Scheef, S. Morabito, A. Caprioli, L. H. Wieler, and H. Karch. 2000. A new Shiga toxin 2 variant (Stx2f) from Escherichia coli isolated from pigeons. Appl. Environ. Microbiol. 66:1205-1208. doi:10.1128/AEM.66.3.1205-1208.2000.

140. Silvestro, L., M. Caputo, S. Blancato, L. Decastelli, A. Fioravanti, R. Tozzoli, S. Morabito, and A. Caprioli. 2004. Asymptomatic carriage of verocytotoxin-producing Escherichia coli O157 in farm workers in northern Italy. Epidemiol. Infect. 132:915-919. doi:10.1017/ S0950268804002390.

141. Sobieszczańska, B. M., R. Gryko, E. Dworniczek, and K. Kuzko. 2004. The carrier state of Shiga-like toxin II (SLT II) and hemolysinproducing enteroaggregative Escherichia coli strain. Pol. J. Microbiol. 53:125-126.

142. Soysal, N., P. Mariani-Kurkdjian, Y. Smail, S. Liguori, M. Gouali, E. Loukiadis, P. Fach, M. Bruyand, J. Blanco, P. Bidet, and S. Bonacorsi. 2016. Enterohemorrhagic Escherichia coli hybrid pathotype $\mathrm{O} 80: \mathrm{H} 2$ as a new therapeutic challenge. Emerg. Infect. Dis. 22:1604-1612. doi:10.3201/eid2209.160304.

143. Stephan, R., S. Ragetti, and F. Untermann. 2000. Prevalence and characteristics of verotoxin-producing Escherichia coli (VTEC) in stool samples from asymptomatic human carriers working in the meat processing industry in Switzerland. J. Appl. Microbiol. 88:335341. doi:10.1046/j.1365-2672.2000.00965.x.

144. Stephan, R., and F. Untermann. 1999. Virulence factors and phenotypical traits of verotoxin-producing Escherichia coli strains isolated from asymptomatic human carriers. J. Clin. Microbiol. 37:1570-1572.

145. Stevens, M. P., P. M. van Diemen, G. Frankel, A. D. Phillips, and T. S. Wallis. 2002. Efa1 influences colonization of the bovine intestine by Shiga toxin-producing Escherichia coli serotypes O5 and O111. Infect. Immun. 70:5158-5166. doi:10.1128/IAI.70.9.5158-5166. 2002.

146. Steyert, S. R., J. W. Sahl, C. M. Fraser, L. D. Teel, F. Scheutz, and D. A. Rasko. 2012. Comparative genomics and stx phage characterization of LEE-negative Shiga toxin-producing Escherichia coli. Front. Cell Infect. Microbiol. 2:133. doi:10.3389/fcimb. 2012.00133.

147. Strachan, N. J. C., D. R. Fenlon, and I. D. Ogden. 2001. Modelling the vector pathway and infection of humans in an environmental outbreak of Escherichia coli O157. FEMS Microbiol. Lett. 203:6973. doi:10.1111/j.1574-6968.2001.tb10822.x.

148. Stritt, A., S. Tschumi, L. Kottanattu, B. S. Bucher, M. Steinmann, N. von Steiger, R. Stephan, H. Hächler, and G. D. Simonetti. 2013. Neonatal hemolytic uremic syndrome after mother-to-child transmission of a low-pathogenic $s x_{2 \mathrm{~b}}$ harboring Shiga toxin-producing Escherichia coli. Clin. Infect. Dis. 56:114-116. doi:10.1093/cid/ cis851.

149. Teunis, P. F. M., I. D. Ogden, and N. J. C. Strachan. 2008. Hierarchical dose response of E. coli O157:H7 from human outbreaks incorporating heterogeneity in exposure. Epidemiol. Infect. 136:761-770. doi:10.1017/S0950268807008771.

150. Teunis, P. F. M., K. Takumi, and K. Shinagawa. 2004. Dose response for infection by Escherichia coli O157:H7 from outbreak data. Risk Anal. 24:401-407. doi:10.1111/j.0272-4332.2004.00441.x.

151. Thomas, A., T. Cheasty, H. Chart, and B. Rowe. 1994. Isolation of vero cytotoxin-producing Escherichia coli serotypes O9ab: $\mathrm{H}^{-}$and O101: $\mathrm{H}^{-}$carrying VT2 variant gene sequences from a patient with haemolytic uraemic syndrome. Eur. J. Clin. Microbiol. Infect. Dis. 13:1074-1076.

152. Tilden, J., W. Young, A. M. McNamara, C. Custer, B. Boesel, M. A. Lambert-Fair, J. Majkowski, D. Vugia, S. B. Werner, J. Hollingsworth, and J. G. Morris. 1996. A new route of transmission for Escherichia coli: infection from dry fermented salami. Am. J. Public Health 86:1142-1145.

153. Tobias, J., E. Kassem, U. Rubinstein, A. Bialik, S.-R. Vutukuru, A. Navaro, A. Rokney, L. Valinsky, M. Ephros, D. Cohen, and K. Muhsen. 2015. Involvement of main diarrheagenic Escherichia coli, with emphasis on enteroaggregative E. coli, in severe non-epidemic pediatric diarrhea in a high-income country. BMC Infect. Dis. 15:79. doi:10.1186/s12879-015-0804-4.

154. Tozzoli, R., A. Caprioli, and S. Morabito. 2005. Detection of toxB, a plasmid virulence gene of Escherichia coli O157, in enterohemorrhagic and enteropathogenic E. coli. J. Clin. Microbiol. 43:40524056. doi.10.1128/JCM.43.8.4052-4056.2005.

155. Tuttle, J., T. Gomez, M. P. Doyle, J. G. Wells, T. Zhao, R. V. Tauxe, and P. M. Griffin. 1999. Lessons from a large outbreak of Escherichia coli $\mathrm{O} 157: \mathrm{H} 7$ infections: insights into the infectious dose and method of widespread contamination of hamburger patties. Epidemiol. Infect. 122:185-192. doi.10.1017/S0950268898001976.

156. U.S. Department of Agriculture, Food Safety Inspection Service. 2011. Shiga toxin-producing Escherichia coli in certain raw beef products. 9 CFR parts 416, 417, and 430. Fed. Regist. 76:5815758165 .

157. Verstraete, K., K. De Reu, S. Van Weyenberg, D. Piérard, L. De Zutter, L. Herman, J. Robyn, and M. Heyndrickx. 2013. Genetic characteristics of Shiga toxin-producing E. coli O157, O26, O103, O111 and O145 isolates from humans, food, and cattle in Belgium. Epidemiol. Infect. 141:2503-2515. doi:10.1017/S0950268813000307.

158. Wagner, P. L., D. W. K. Acheson, and M. K. Waldor. 1999. Isogenic lysogens of diverse Shiga toxin 2-encoding bacteriophages produce markedly different amounts of Shiga toxin. Infect. Immun. 67:67106714.

159. Weeratina, R. D., and M. P. Doyle. 1991. Detection and production of verotoxin 1 of Escherichia coli O157:H7 in food. Appl. Environ. Microbiol. 57:2951-2955.

160. Werber, D., S. C. Behnke, A. Fruth, R. Merle, S. Menzler, S. Glaser, L. Kreienbrock, R. Prager, H. Tschäpe, P. Roggentin, J. Bockemühl, and A. Ammon. 2007. Shiga toxin-producing Escherichia coli infection in Germany-different risk factors for different age groups. Am. J. Epidemiol. 165:425-434. doi:10.1093/aje/kwk023.

161. Wirth, T., D. Falush, R. Lan, F. Colles, P. Mensa, L. H. Wieler, H. Karch, P. R. Reeves, M. C. J. Maiden, H. Ochman, and M. Achtman. 2006. Sex and virulence in Escherichia coli: an evolutionary perspective. Mol. Microbiol. 60:1136-1151. doi:10.1111/j.13652958.2006.05172.x.

162. Zhang, W. L., M. Bielaszewska, A. Liesegang, H. Tschäpe, H. Schmidt, M. Bitzan, and H. Karch. 2000. Molecular characteristics and epidemiological significance of Shiga toxin-producing Escherichia coli O26 strains. J. Clin. Microbiol. 38:2134-2140. 
163. Zhang, W. L., A. Mellmann, A. K. Sonntag, L. Wieler, M. Bielaszewska, H. Tschäpe, H. Karch, and A. W. Friedrich. 2007. Structural and functional differences between disease-associated genes of enterohaemorrhagic Escherichia coli O111. Int. J. Med. Microbiol. 297:17-26. doi:10.1016/j.ijmm.2006.10.004.
164. Zweifel, C., N. Cernela, and R. Stephan. 2013. Detection of the emerging Shiga toxin-producing Escherichia coli O26:H11/ $\mathrm{H}^{-}$ sequence type 29 (ST29) clone in human patients and healthy cattle in Switzerland. Appl. Environ. Microbiol. 79:5411-5413. doi:10. 1128/AEM.01728-13. 